\title{
DE LA ESCUELA APOSENTO A LA ESCUELA «PRESIDENTE TRUJILLO». TRANSFORMACIONES ESPACIALES Y GENEALÓGICAS EN LA ESCUELA RURAL DOMINICANA, 1844-1944
}

\author{
From Chamber-School to the "President Trujillo"School. Spatial \\ and genealogical transformations in the Dominican rural school, \\ 1844-1944
}

\section{Juan B. Alfonseca Giner de los Ríos*}

Fecha de recepción: 30/03/2017 • Fecha de aceptación: 25/05/2017

Resumen. El tránsito histórico al que alude este escrito describe el proceso de formación del sistema de escolarización de masas moderno en la República Dominicana. Parcialmente pública en sus inicios republicanos, cuando emergió de la entraña del espacio domiciliar del profesorado, la educación provista por el Estado avanzaría lentamente hacia formas más plenas de libre acceso a la escuela. Entre las cuasi públicas escuelas-aposento de 1844 y las escuelas «Presidente Trujillo» de la dictadura dominicana nacidas en 1933, se verifica no sólo el progreso del acceso libre y gratuito del ciudadano a la enseñanza pública, sino la transformación profunda del espacio y las relaciones sociales que daban vida a la escuela.

Este escrito analiza la gran transformación que comportó la eclosión de las escuelas «Presidente Trujillo», como modalidad escolar basada en el espacio aislado, de propiedad pública, al que podía gratuitamente acceder la población rural. Aunque focalizaremos el proceso de transformación del espacio escolar rural, nuestro principal interés analítico reside en la configuración y el cambio en las relaciones sociales entramadas por el desarrollo de la enseñanza pública, entendiendo por tales tanto las basadas en procesos de poder e interés derivados de la articulación entre poder público y estructuras sociales como las fundadas en la epistemología social que pretendió regularla durante el primer siglo de vida republicana de la sociedad dominicana (1844-1944).

Palabras clave: Espacio escolar; epistemología social; sistema de escuela pública; poder; genealogía.

\footnotetext{
"Instituto Superior de Ciencias de la Educación del Estado de México. Ex Rancho Los Uribe. Santa Cruz Atzcapotzaltongo. Toluca. Estado de México. México.j_alfonseca@yahoo.es
}

Cómo citar este artículo: Alfonseca Giner de los Ríos, Juan B. «De la escuela aposento a la escuela "Presidente Trujillo". Transformaciones espaciales y genealógicas en la escuela rural dominicana, 1844-1944». Historia y Memoria de la Educación 7 (2018):107-151. 
Abstract. The historical transition referred to in this paper describes the development of the modern mass schooling system in the Dominican Republic. It was partially public in its republican beginnings, when it emerged from the heart of the teacher's home space under the model we call chamber-school, an education provided by the state that would slowly move towards more complete forms of free access to school. Between the 1844 quasi-public chamber-schools and the "Presidente Trujillo» schools of the 1930-1961 dictatorship, citizens' open and free access to public education took place, accompanied by a profound transformation of spatial and social relations that gave life to the school.

This paper analyzes the great transformation that the emergence of the "Presidente Trujillo" schools represented, as a school system based on a publicly-owned, isolated space, one which the rural population could access freely. Although we focus on the process of rural school spatial transformation, our main analytical interest lies in the configuration and change of social relationships that the development of public education entailed. We wish to understand both those relationships based on processes of power and interest derived from the articulation between the State and civil society; for example, those processes founded on the social epistemology that intended to regulate education during the first century of republican life of Dominican society (1844-1944).

Keywords: School space; social epistemology; public school system; power; genealogy.

\section{INTRODUCCIÓN}

Fue por un gesto de desprendimiento patrio, en la primera Navidad que vivían los dominicanos como pueblo independiente, por lo que circuló un 24 de diciembre de 1844 en las calles del viejo Santo Domingo de Guzmán una hoja suelta en la que el maestro Manuel Aybar declaraba:

Habiéndome encargado el Gobierno la dirección de la escuela primaria, facultándome a tomar por mi propia cuenta los demás niños que me sean convenientes, hago saber que tendrá lugar la apertura de dicho establecimiento el día dos de enero del año entrante, en mi misma casa, por un favor particular. Aquellos que vinieren provistos de una orden del Secretario de Estado del Despacho de Justicia, Instrucción Pública y Relaciones Extranje- 
ras, su enseñanza es gratuita, en cuyo número se preferirán los hijos de militares que hayan servido a la Patria o de personas pobres que no puedan por sí satisfacerla. ${ }^{1}$

Uno entre la corta lista de preceptores particulares de la ciudad en aquel aciago año de la independencia nacional, el aviso de Aybar sentaba los términos de su compromiso con el ideario patrio: recibir gratuitamente en su escuela a quienes portasen orden del Secretario del nuevo despacho de Instrucción Pública, lo mismo que a personas sin recursos para pagar la matrícula que continuarían aportándole un cierto número de niños que le fuesen «convenientes». Además de su esfuerzo, "como un favor particular» el maestro aportaría también a la gesta de la escuela pública el espacio de su propia casa.

Replicado seguramente por otros maestros, con el gesto de Aybar nacía la escuela pública dominicana del primer período republicano. ${ }^{2}$ Bajo fórmulas que distaban de lo que por tal se entendería setenta años después, con la reforma escolar implantada por la Ocupación militar norteamericana de 1916-1924, ${ }^{3}$ que sentó las bases para el desarrollo de un sistema moderno de escuela pública al servicio de la formación del Estado nacional, que luego re-articularía la dictadura de Rafael L. Trujillo (1930-1961), profundizándolo hasta hacer emerger el moderno sistema de escuela pública en el país.

\footnotetext{
${ }^{1}$ Citado en: Emilio Rodríguez Demorizi, Sociedades, cofradías, escuelas, gremios y otras corporaciones dominicanas (Santo Domingo: Editora Educativa Dominicana, 1975), 174.

${ }^{2}$ Quizás por haberse educado en su escuela el patricio Juan Pablo Duarte, la efeméride de Aybar ha sido consignada como la del "primer maestro oficial que tuvo el naciente Estado», cosa que quizá sólo sea un dejo literario, pues existía interés por la enseñanza pública en muchos otros puntos del país. Francisco Antonio Pimentel, Historia de la educación en la República Dominicana (Santo Domingo: Editora Centenario, 2003), 86.

${ }^{3}$ Pretextando la incapacidad del Estado nacional para honrar acreencias financieras internacionales, la Infantería de Marina de los Estados Unidos inició en mayo de 1916 la ocupación militar de la República Dominicana, nación en la que permaneció hasta 1924. La ocupación formó parte de la política de dominio imperial desarrollada por los Estados Unidos en las Antillas desde 1898, cuando colonizaron Cuba y Puerto Rico, reeditándose luego en Haití (1915) y la República Dominicana. Las cuatro ocupaciones conllevaron hondas transformaciones de los sistemas escolares nacionales, que tendieron a centralizarse y a uniformarse. De hecho, la construcción de genuinos «sistemas de escuela pública» se convirtió en argumento legitimador de los actos de ocupación. Juan Alfonseca, «A Public School System. Ensayo sobre un concepto en la representación imperial norteamericana sobre la escuela popular en las Antillas, 1898-1934», en El lenguaje de la educación: conceptos, metáforas y narrativas en los orígenes de los sistemas educativos nacionales (c.1870-1930), editor Eugenia Roldán Vera (Frankfurt am Main: Peter Lang) (en prensa).
} 
Hasta que llegó este momento, el patrón de escuela pública proporcionado por el mítico maestro Manuel Aybar dominó en la escolarización dominicana. En este escrito llamaremos a ese patrón o modalidad de desarrollo de la institución escolar Escuela-aposento.

El tránsito histórico al que alude el título de este escrito, describe el proceso de formación del sistema de escolarización de masas moderno en la República Dominicana. Parcialmente pública en sus inicios republicanos, cuando emergió en la entraña del espacio domiciliar del profesorado, la educación provista por el Estado avanzaría lentamente hacia formas más plenas de libre acceso a la escuela; formas cuya aparición supuso la transformación del espacio y de las configuraciones sociales y políticas que habían sustentado hasta entonces la escuela. Entre la cuasi pública escuela-aposento del maestro Aybar, en 1844, y las escuelas «Presidente Trujillo» de la dictadura dominicana de los años treinta del siglo pasado, se verificó no sólo el progreso del acceso libre y gratuito del ciudadano a la enseñanza pública, sino la transformación profunda del espacio y las relaciones sociales que daban vida a la escuela.

Este escrito analiza la gran transformación que comportó la eclosión de las escuelas «Presidente Trujillo» en 1933, como modalidad basada en el espacio aislado, de propiedad pública, al que podía gratuitamente acceder la población rural. Se trata de un estudio exploratorio, basado en fuentes de la Secretaría de Justicia e Instrucción Pública, amén de los contados estudios disponibles sobre la historia escolar de la República Dominicana. ${ }^{4}$

\footnotetext{
${ }^{4}$ Poseedora de una rica historia educacional — que comprende desde el accionar de educacionistas insignes como Eugenio María de Hostos, intelectual de talla continental, hasta el empleo de la escuela pública como auténtico aparato ideológico en favor del Estado totalitario-, lastima la corta bibliografía general existente, esencialmente reducida a: Danilo De los Santos, «El pensamiento y la institución educativa en la sociedad dominicana», Revista Eme-Eme, 4, (1978); José A. Fiallo y Alejandrina Germán, Formación de maestros y maestras en República Dominicana, 1844-1992 (Santo Domingo: INTEC, 1999); Raymundo González, Documentos para la historia de la educación moderna en la República Dominicana (1879-1894), Tomo I y II, (Santo Domingo: Archivo General de La Nación, 2007); Jacobo Moquete, Filosofía y política de la educación dominicana (Santo Domingo: Editora Universitaria, 1986); Ramón Morrison, Historia de la educación en la República Dominicana (Desde sus más remotos orígenes hasta 1900) (Santo Domingo: Editora Taller, 1995); Consuelo Nivar, Sistema educativo en la República Dominicana (Ciudad Trujillo: Librería Dominicana, 1952); Gregorio B. Palacín, «Cien años de educación nacional», Revista de Educación, 73 y 74 (1944); Roberto Santos, Pasado, presente y perspectivas de la educación nacional institucionalizada (Santo Domingo: Editora Alfa y Omega, 1983), amén de los trabajos antes citados de Demorizi y Pimentel. El lapso que va de
} 
Aunque focalizaremos el cambio del espacio escolar rural, nuestro principal interés analítico lo es la configuración y el cambio en las relaciones sociales entramadas por el desarrollo de la enseñanza pública, entendiendo por tales tanto las basadas en procesos de poder e interés derivados de la articulación entre el poder público y las estructuras sociales como las fundadas la epistemología que pretendió regularla durante el primer siglo de vida republicana (1844-1944). ${ }^{5}$

Organizamos esta exposición en tres giros argumentales. El primero de ellos - La Escuela-Aposento-, trata sobre la emergencia de esta modalidad escolar en el tránsito del pueblo dominicano a la condición de nación independiente (1844) y examina sus tendencias de expansión durante los poco más de setenta años que median entre el nacimiento de la república y su parcial suspensión por la intrusión del poder imperialista norteamericano en 1916. El segundo - Hacia la escuela «Presidente Trujillo»: la ocupación norteamericana y la reforma escolar, 1918-1924trata sobre el ocaso del modelo de escuela-aposento que había sustentado la expansión de la enseñanza primaria pública dominicana hasta entonces por los obstáculos que este planteaba a la reforma educacional impulsada por la ocupación militar, que fue la que hizo propiamente emerger el sistema de escolarización pública de masas en la sociedad dominicana, creando las bases jurídicas e institucionales para su posterior profundización y consolidación durante la dictadura de Rafael L. Trujillo (1930-1961), cuando el modelo escolar de escuela rural basado en el espacio aislado, de propiedad pública, se entronizó como mecanismo de

la ocupación norteamericana a la entronización de la dictadura de Rafael L. Trujillo (1916-1935), apenas ha sido abordado en los estudios de Bruce Calder, El impacto de la intervención. La República Dominicana durante la Ocupación Norteamericana de 1916-1924 (Santo Domingo: Fundación Cultural Dominicana, 1989) y A. J. Angulo, Empire and Education. A History of Greed and Goodwill from the War of 1898 to the War on Terror (New York: Palgrave Macmillan, 2012). Aunque cuenta con una extensa bibliografía apologética, el lapso de la dictadura trujillista apenas ha sido abordado. Equipo de Investigaciones Sociales, «La educación bajo la dictadura trujillista: una bibliografía», Ciencia y Sociedad, 12 (1), (1987).

${ }^{5}$ Aludimos la presencia de un campo epistemológico y genealógico a título indicativo, brindando esporádicas referencias, por imposibilidad de comprometer —en el marco de este escrito- el análisis del papel jugado por el conocimiento en el establecimiento de marcos legítimos de acción en la enseñanza pública y, por ende, de las bases epistemológicas de las relaciones de poder genealógicas que proporcionó el avance y la reforma de la escuela pública dominicana al cabo de esa centuria. Inspiramos nuestra lectura en las ideas de Popkewitz y Marshall sobre el conocimiento, la genealogía y la reforma escolar. Thomas Popkewitz, Sociología política de las reformas educativas (Madrid: Ediciones Morata, 1994); James D. Marshall, "Foucault y la investigación educativa», en Foucault y la educación. Disciplinas y saber, editor Stephen J. Ball (Madrid: Ediciones Morata, 1994), 15-33. 
encuadramiento social del campesinado, circunstancia que constituye la materia del tercer giro argumental —La escuela «Presidente Trujillo» y el encuadramiento social del campesinado dominicano, 1933-1944-.

En el curso de nuestra argumentación ilustraremos, sustantivamente, cómo la emergencia del moderno sistema de escuela pública de masas supuso, en la formación social dominicana como lo supuso también invariantemente en el plano internacional, la pugna entre niveles de poder y jurisdicción de municipios, provincias y gobierno nacional. El proceso de centralización del sistema en favor de este último conllevaría la disolución y la rearticulación de los sistema de relaciones sociales de poder y genealogía que sustentaban la escolarización en el medio rural.

\section{LA ESCUELA-APOSENTO}

La patriótica iniciativa de Aybar ilustra la génesis de la escuela-aposento como modelo que protagonizaría el desarrollo de la escuela pública dominicana durante décadas, dotándola de una escena material y de un entramado de relaciones de poder que sólo podría conmover la intrusión de un poder externo. En aquél 1844, Aybar era uno entre los varios preceptores particulares que típicamente regenteaban escuelas en su propio domicilio. Conducía una escuela privada que devino pública por efecto del exhorto patrio del nuevo gobierno, que le encargó recibir alumnos remitidos por la Secretaría del ramo. Así, en la nueva trama republicana, a la escuela de Aybar concurrirían en lo sucesivo dos tipos de alumnos: los visados por el gobierno central y los que pagaban por aprender. Los segundos se conocerían como particulares o pensionistas; los primeros de modo gratuito o público, gracias al subsidio que — seguramente- le retribuyó el gobierno por recibirlos, como tendería a practicarse desde entonces.

En las precarias condiciones fiscales de temprana independencia, la existencia de ese sector de escuelas-aposento privadas fue la que permitió al naciente Estado nacional concretar el compromiso con la enseñanza pública que mandaba la Constitución, ${ }^{6}$ instaurándose un modelo de cultura escolar que perviviría por décadas.

\footnotetext{
${ }^{6}$ «Será creada la instrucción pública, común a todos los ciudadanos, gratuita en todos los ramos de la enseñanza primaria», rezaba la primera constitución votada en San Cristóbal en 1844. Constitu-
} 
Así, hacia 1860, de las 35 escuelas primarias existentes en la ciudad capital de Santo Domingo sólo cuatro eran públicas y operaban bajo el modelo domiciliar descrito con alumnos subvencionados por el Ayuntamiento y alumnos pensionistas. ${ }^{7}$ También por esos días, la progresista ciudad de La Vega contaba enseñanza pública en planteles que Hernández describe así: «Una escuela la integraba un preceptor con un grupo de alumnos o un director y uno o dos maestros ayudantes y sus alumnos [...] las clases se impartían en la misma casa del preceptor o en una enramada anexa». ${ }^{8}$

Veinte años más tarde, el modelo de escuela-aposento predominaba como realidad básica de la enseñanza provista por el Estado, asistiendo alumnos públicos a escuelas particulares domiciliares, cuyos preceptores recibían subvención del Ayuntamiento por hacerlo. Los censos escolares impulsados por la Secretaría de Estado de Justicia, Fomento e Instrucción Pública entre 1881 y 1883, lo revelan como espacio característico de la enseñanza pública ofrecida en las Comunes que contaban con ella. ${ }^{9}$

Pocos locales de escuela a finales del XIX eran de propiedad pública; generalmente, los ayuntamientos los rentaban. Muchos de ellos eran propiedad del maestro, que instalaba la escuela en aposentos del propio domicilio, o en aposentos del domicilio de otros vecinos o de viviendas desocupadas poseídas por éstos; en muy raras ocasiones, tales viviendas habían sido construidas con ese fin. ${ }^{10}$

ción política y reformas constitucionales 1844-1942 Tomo I, (Santiago de los Caballeros: Editorial El Diario, 1934), 14.

${ }^{7}$ Revista Quincenal Dominicana, 8, (1860). Citada por Demorizi, Sociedades, cofradías, 174.

${ }^{8}$ Alfredo Hernández Figueroa, La Vega, 25 años de historia. 1861 - 1886. Tomo II (Santo Domingo: Archivo General de la Nación, 2007), 22.

${ }^{9}$ La Común es una unidad política equivalente al Municipio. No todas las Comunes del país contaban con escuela pública en 1880. Existía en las más ricas, acrisolando cierta tradición escolar las de Santo Domingo, Santiago, Puerto Plata, La Vega, Moca, Montecristi y San Pedro de Macorís. Sin embargo, no pocas de la zona fronteriza, de la llanura oriental y del macizo montañoso del suroeste carecían de ella.

${ }^{10}$ Una descripción de la escuela municipal de Azua muestra rasgos del espacio domiciliar privado en que se albergaba: «su local, que gana del municipio $\$ 7$ de alquiler, carece de las condiciones que debe tener un edificio destinado a la instrucción, pues [...] los dos salones de que se compone [no] se prestan a una organización eficaz entre 40 alumnos al cuidado de un solo profesor». Junta Provincial de Estudios, febrero 1881, Justicia e Instrucción Pública, legajo 300216, Archivo General de la Nación (AGN). 


\section{Cuadro 1}

Inscripción escolar según tipo de matrícula en comunes dominicanas 1881-1883

\begin{tabular}{|c|c|c|c|c|}
\hline Común & Nombre del plantel & Municipio & Particular & Gratis \\
\hline \multirow{4}{*}{ Azua } & De Niñas & 41 & 4 & 3 \\
\hline & De ambos sexos & & 10 & 21 \\
\hline & Municipal Nº 1 & 30 & 13 & 11 \\
\hline & Preparatoria & 17 & 3 & \\
\hline Barahona & De Niños & 18 & 16 & \\
\hline Bonao & Municipal de Niños & 10 & 5 & \\
\hline Hato Mayor & De Varones & 10 & 7 & \\
\hline \multirow{3}{*}{ Higuey } & Municipal y Particular de niñas 1 & 12 & 10 & \\
\hline & Municipal y Particular de niñas 2 & 12 & 11 & \\
\hline & Municipal y Particular de Niños & 14 & 29 & \\
\hline \multirow{3}{*}{ La Vega } & De Niños del Corozo & 10 & 6 & 1 \\
\hline & Municipal de Niñas & 29 & 2 & 9 \\
\hline & Municipal de Niñas "Los Ángeles" & 20 & & 6 \\
\hline \multirow{3}{*}{ Moca } & El Corazón de Jesús & 40 & 12 & 5 \\
\hline & Santa Ana & 40 & 6 & 64 \\
\hline & Particular incompleta de Juan López & 10 & 27 & \\
\hline \multirow[t]{3}{*}{ Monte Cristy } & Superior de Varones & 20 & 11 & 15 \\
\hline & Particular de Niñas & & 5 & 25 \\
\hline & De Varones de Guaraguanó & 18 & & 3 \\
\hline \multirow[t]{2}{*}{ Ocoa } & De Niños & 13 & 12 & \\
\hline & Municipal de Niñas La Caridad & 20 & 9 & 10 \\
\hline \multirow{3}{*}{ Puerto Plata } & Municipal de Niñas La Inmaculada & 20 & 2 & 8 \\
\hline & Municipal de Niñas La Fe & 20 & 6 & \\
\hline & Municipal de Niñas La Esperanza & 20 & 5 & \\
\hline \multirow{2}{*}{ Sabaneta } & Municipal de Niños & 20 & 11 & 15 \\
\hline & Municipal de Niñas & & 5 & 25 \\
\hline Samaná & Municipal & 19 & 17 & \\
\hline San Cristóbal & Clase Municipal y Particular de la Común & 20 & 14 & \\
\hline \multirow{9}{*}{ Santiago } & San José & 33 & 24 & 54 \\
\hline & Santa Teresa de Jesús & 32 & 11 & 5 \\
\hline & De Hembras & 30 & 4 & 3 \\
\hline & Elemental de Marilópez & 25 & 1 & 20 \\
\hline & Elemental de Cruz de Licey & 20 & 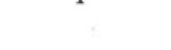 & \\
\hline & Elemental de Guazumal & 26 & & 9 \\
\hline & Elemental de Gurabo & 28 & & \\
\hline & Elementai de Canca & 30 & & \\
\hline & Elemental de Palmar & 16 & & \\
\hline
\end{tabular}

Fuente: elaborado a partir de expedientes de la Secretaría de Justicia e Instrucción Pública. 
El cuadro anterior muestra el carácter parcialmente público que ostentaba lo que se conocía como "escuela pública», institución que típicamente integraba en su matrícula los tipos de alumno señalados — públicos y pensionistas-, si bien ya para entonces existe una curiosa tercer categoría: los gratuitos. ${ }^{11}$

Aunque la documentación de las Juntas Provinciales de Estudios suele consignar el estatuto jurisdiccional del local escolar con categorías como Propio, Del Ayuntamiento o Alquilado, no incluimos en el cuadro esa información por no ser unívoca. En especial, la categoría "propio» crea duda, pues se la empleó tanto para señalar que el local era propiedad del Ayuntamiento como de que lo era del maestro. Generalmente resultaba lo segundo, pues resultaba atractivo para el erario comunal el que el maestro entregase sin costo (como lo hiciere antes el maestro Aybar) un aposento del domicilio como espacio para la escuela o que, incluso, cobrase una módica suma por el alquiler del mismo. ${ }^{12}$

Al doblar del siglo, la escuela-aposento hegemonizaba el desarrollo escolar dominicano, cosa que sucedía a pesar de la labor crítica del movimiento normalista inspirado por el educador puertorriqueño Eugenio María de Hostos. ${ }^{13}$ Según un informe elaborado por el inspector de escuelas municipales de la ciudad de Puerto Plata en 1890, más de la mitad de los planteles a los que asistían alumnos públicos se alojaban en el domicilio de los preceptores. ${ }^{14}$ Incluso en la ciudad de Santo Domingo,

\footnotetext{
${ }^{11}$ Hoy, el alumno del plantel público asiste gratuitamente; la curiosidad que se señala deriva del hecho de que el alumno gratuito ostentase - tal y como lo rezan las anotaciones a los registros escolares de la época «Pobreza de Solemnidad»- y que el "público» pudiese, incluso, ser relativamente pudiente. Sin duda, la propia constitución histórica de los conceptos entrañaba distintas genealogías sociales en relación con la entrañada por las categorías de adscripción gestadas por la escolarización pública de masas. Sobre el valor heurístico del estudio del movimiento histórico de los conceptos educacionales puede verse, por ejemplo, el trabajo de Eugenia Roldán. Eugenia Roldán Vera, «Instrucción pública, educación pública y escuela pública: Tres conceptos clave en los orígenes de la nación mexicana, 1780-1833», en Escuela Pública y Maestro en América Latina. Historias de un acontecimiento, siglos XVIII-XIX, editores Alberto Martínez Boom y José Bustamante Vismara (Buenos Aires, Prometeo, 2014).

${ }^{12} \mathrm{Al}$ consignar el gasto en alquiler de local, algunos reportes municipales lo indican señalando cosas aparentemente paradójicas como: «Dos pesos ( $2 \$$ mensuales; Propio».

${ }^{13}$ González, Documentos para la historia, Tomo I, 1-33.

${ }^{14}$ Informe del Inspector Examinador de las Escuelas Municipales y Discursos pronunciados en el Colegio «El Nacional» (Puerto Plata: Ayuntamiento de Puerto Plata, 1890).
} 
cuna del normalismo, el informe que el Inspector Médico de Escuelas rindió sobre el ciclo escolar de 1915-1916 señalaba:

Todas las escuelas primarias están instaladas en viviendas particulares que por sus condiciones higiénicas son, por regla general, inadaptables para destino escolar, pues además de ser sus departamentos de escasas dimensiones, caprichosamente distribuidos, carecen de luz apropiada, de ventilación suficiente y sus patios son por lo regular tan reducidos que no pueden destinarse a esparcimiento de los niños. ${ }^{15}$

Aún en 1919, al cumplirse el segundo año de la reforma implantada por el gobierno militar, $45 \%$ de las escuelas urbanas y $62 \%$ de las rurales de la provincia de Puerto Plata se alojaban en viviendas que recibían uso escolar y habitacional, según consigna el censo provincial realizado ese año, hecho que muestra la persistencia del modelo en áreas urbanas y su difusión en los campos, que habían venido escolarizándose desde principios de siglo, principalmente desde el gobierno modernizador del general Ramón Cáceres (1907-1911). ${ }^{16}$

\section{La escuela-aposento y su inserción política y genealógica en el orden pueblerino}

La expansión de la enseñanza pública mediante la subsunción de la escuela-aposento particular tendió a configurar estructuras de interés y poder basadas en su pervivencia como modelo de escolarización. Resulta importante analizarlas por ser éstas las que protagonizaron el sordo debate sobre el establecimiento de un sistema de escuela pública que implicó la reforma de la ocupación norteamericana.

\footnotetext{
${ }^{15} \mathrm{El}$ informe brinda rasgos interesantes del orden cotidiano de la escuela-aposento: «he ordenado la clausura temporal de las escuelas Doña Mencía y M. ${ }^{a}$ Nicolasa Billini; la primera en febrero de 1916 por haberse registrado dos casos de fiebre tifoidea en dos niños que habitaban en el mismo local: la segunda en abril por haber un caso de sarampión en un departamento contiguo al que se utiliza para las clases». Informe médico-higiénico de las escuelas públicas de la ciudad de Santo Domingo. Año lectivo 1915-1916 (Santo Domingo: Impresora «Renacimiento», 1916), 4.

${ }^{16}$ Censo de la común de Puerto Plata conteniendo otros datos estadísticos relativos a la misma y a la Provincia (Puerto Plata: Ayuntamiento de Puerto Plata, 1919).
} 
Como fue señalado, la escuela-aposento particular constituyó el espacio idóneo para que los ayuntamientos estableciesen la enseñanza pública en condiciones de costo adecuadas a sus rentas. De la circunstancia del mítico desprendimiento del maestro Aybar con que cobró vida a las realidades de los años posteriores, se afianzó en los ayuntamientos una suerte de pragmatismo económico, expreso en la descripción que hacía en 1883 el Gobernador de la provincia de Santiago al señalar: "Considero oportuno manifestar a Ud. que a excepción del local del Colegio Central Municipal, que cuesta al Ayuntamiento cincuenta y cinco pesos [...] los locales de las demás escuelas son propiedad de sus respectivos profesores, razón por la cual notará Ud. que no se paga por ellos alquiler alguno». ${ }^{17}$

De parte de los Ayuntamientos pareció existir ese tipo de racionalidad. De los 55 pesos fuertes que pagaba un Ayuntamiento como el de Santiago por el local donde operaba el Colegio Central, con sus 216 alumnos, a los dos, tres o cinco pesos que se solían pagar por los locales y aposentos que ocupaban las pequeñas escuelas de 40 alumnos en cualquiera de las comunes del país, resultaba evidente el atractivo "costo de oportunidad» que tal tipo de relación representaba para las rentas comunales.

Una suerte de mercado, atravesado por múltiples formas de poder e influencia, pareció existir en los pueblos en torno a las subvenciones dinerarias destinadas por los ayuntamientos al fomento escolar. Parentescos, relaciones cotidianas, formas de interés, eventualmente políticas partidarias pueblerinas, fueron factores que incidieron en la decisión de los ayuntamientos por contratar a tal o cual maestro, arrendar tal o cual vivienda como plantel o, incluso, decidir por cuál de las secciones rurales sujetas a la cabecera habría de iniciar la implantación de la escuela pública.

Una auténtica micropolítica local tendía su arena en derredor de la escuela-aposento y su pervivencia, modelo que fue foco de crítica permanente por parte de la intelectualidad normalista, que denunciaba los costos pedagógicos que representaba su sostenimiento. Su pervivencia no se basaba, como lo afirmaba en 1895 el presidente saliente del Ayuntamiento de Santo Domingo, en una suerte de política de corte humani-

\footnotetext{
${ }^{17}$ Pichardo, agosto 1883, Justicia e Instrucción Pública, legajo 300216, AGN.
} 
tario («Obstáculos insuperables se han opuesto siempre a una reforma escolar; el aterrador fantasma de la miseria en que quedarán sumidos los actuales directores de esos planteles, ha detenido al Municipio en tan urgente necesidad!), ${ }^{18}$ sino en vínculos concretos y diferenciables entre actores de poder, como directamente lo denunciaría el intendente José Dubeau al informar sobre el impacto que la política tenía en el perfil pedagógico de las escuelas rurales de la provincia de Santiago:

Debo decirle [...] que el Poder Ejecutivo ha extendido nombramiento para Directores de varias escuelas, entre ellos a la Sra. Julia viuda Grau, para la escuela de Pastor que es municipal, donde había yo designado provisionalmente a la Sta. Mercedes Espinal, mui competente, mui virtuosa, en virtud de que la viuda Grau me había asegurado que no solicitaría. Del modo como pasan las cosas, el Intendente aquí es una irrisión porque cuando me niego a algo que me solicitan porque la lei no lo permite me contestan que «recurren a mí por pura forma, porque no tienen más que escribir a la Capital, i en el acto lo consiguen» [...] ¿Cómo puede ser que yo recomiende para puestos de escuelas a uno o más aspirantes, i que luego me sorprenda el nombramiento para alguno de cuya solicitud no he conocido? ${ }^{19}$

La razón pedagógica del intendente Dubeau se enfrentaba con la política clientelar del Ejecutivo nacional en 1916, cosa que revela un aspecto del tipo de politiqueo partidario que pesaría sobre los ideales de mejora del cuerpo enseñante nacional durante muchos años más. Sin embargo, treintaicinco años atrás, en la provincia de Azua, era el ayuntamiento constitucional el que mostraba otra de las facetas de ese accionar político en derredor de los maestros y los espacios de enseñanza pública, al defender la autonomía del municipio (común) de la injerencia del nivel provincial a propósito del Sr. Romero Lujando, maestro de la escuela primaria de la cabecera, a quien se había autorizado a dar cabida en el plantel a un cierto número de alumnos pensionistas, cosa que objetaba

${ }^{18}$ González, Documentos para la historia, Tomo II, 337.

${ }^{19}$ José Dubeau, marzo de 1916, Justicia e Instrucción Pública, expediente 1/663, AGN. 
la Junta Particular de Estudios, acusándolo de violar el artículo 52 del Reglamento de Educación por hacerlo.

La Junta provincial exigía al Ayuntamiento la retirada de los alumnos pensionistas del plantel municipal; el Ayuntamiento decidía no retirarlos en atención no sólo al interés de los padres de los alumnos particulares que quedarían sin escuela, sino por considerar que:

Aun cuando a las Juntas Provinciales les fuera potestativo ejercitarlas, de ningún modo podría ser con un carácter omnímodo y haciendo caso omiso de la atención debida a la cosa ajena o sea la Escuela Municipal que es del Pueblo i pagada por el Pueblo [...] dicho Reglamento, [...] es ya una lei que, en su Art. 52 es mui concreta a las Escuelas del Gobierno, i éste no es el Municipio, puesto que aquél subvenciona los Institutos que crea con los fondos públicos, y éste, con los comunales que por su procedencia y aplicación se hallan respecto de sí, en posición diametral. ${ }^{20}$

El presidente del ayuntamiento parecía no captar el nuevo orden de jurisdicciones que legitimaba la intrusión de los niveles superiores de la política y la administración del Estado nacional. Con razón o sin ella, reclamaba la autonomía de sus actos con base en una exégesis jurídica que remataba concluyendo «i como por nuestra lei sustantiva, a nadie se le puede impedir de hacer lo que ella no prohíbe, esta Corporación [...] no objetó el ingreso a su Instituto del pequeño número de niños extraños».

Inteligible como expresión del proceso de resta de atributos de jurisdicción al municipio que entrañaría la formación del Estado Docente latinoamericano, ${ }^{21}$ el incidente brinda posiblemente indicio de que resistencias similares interviniesen también en la configuración de las complejas matrículas que contiene el Cuadro 1, en las que puede frecuentemente verse la coexistencia de alumnos públicos y particulares. Un orden de afinidades local maestro-ayuntamiento-espacio combatía con otro, de nivel provincial, sometido al que, desde el núcleo en centralización del

\footnotetext{
${ }^{20}$ J. Miranda, febrero de 1881, Justicia e Instrucción Pública, legajo 300216, AGN.

${ }^{21}$ Carlos Newland, «The Estado Docente and Its Expansion: Spanish American Elementary Education, 1900-1950», Journal of Latin American Studies, 26 (2), (1994): 449-467.
} 
Estado nacional, actuaba con la armas de la razón sobre el modo de organizar y sancionar la enseñanza.

Poder y genealogía; genealogías del nuevo poder formativo que pugnaba por el sistema de escuela pública dominicano que comenzaría a cobrar forma con la Ocupación norteamericana. Como un rasgo revelador en el sentido genealógico del poder-conocimiento que entramó el incidente del maestro Romero Lujando, es de señalarse evidencia lateral de procesos de resistencia cultural local a la implantación de la pedagogía hostosiana. Su implantación era recomendada por el Ministerio de Justicia e Instrucción Pública, asunto que el propio Romero Lujando había combatido en páginas del Eco de la Opinión. ${ }^{22}$

Iluminar la condición y difusión de la escuela-aposento en el medio rural en el lapso 1844-1880 resulta una tarea factualmente limitada. Por una parte, porque la extensión de la enseñanza pública al campo apenas comenzó a tomar fuerza a la vuelta del siglo XIX, resultando contados los establecimientos que consignan las Juntas Provinciales antes de esa fecha. Por la otra, porque los reportes de las Juntas provinciales dan generalmente un tratamiento escueto a los establecimientos de pueblos y secciones rurales sujetas a cabecera comunal o provincial, brindando poco detalle sobre sus formas de operación.

A pesar de esas carencias, nada permite pensar que la realidad rural de la enseñanza pública escapase al modelo domiciliar descrito hasta aquí. A lo más, en el medio rural el modelo habrá editado sus rasgos más precarios y expuestos a los vaivenes del erario comunal.

Samuel Hazard, un viajero que describió el país hacia 1870 legó una representación aproximada del tipo de espacio escolar rural en ese último cuarto de siglo.

\footnotetext{
${ }^{22}$ En carta al Ministro de Justicia e Instrucción Pública, el profesor Romero Lujando mostraba su desacuerdo con la pedagogía hostosiana que se quería implantar, refiriéndole su «Disertación sobre libertad de enseñanza» aparentemente editada por El Eco de la Opinión. E. Romero, abril de 1881, Justicia e Instrucción Pública, legajo 300216, AGN.
} 


\section{Escuela dominicana. Grabado de Samuel Hazard (circa 1870)}

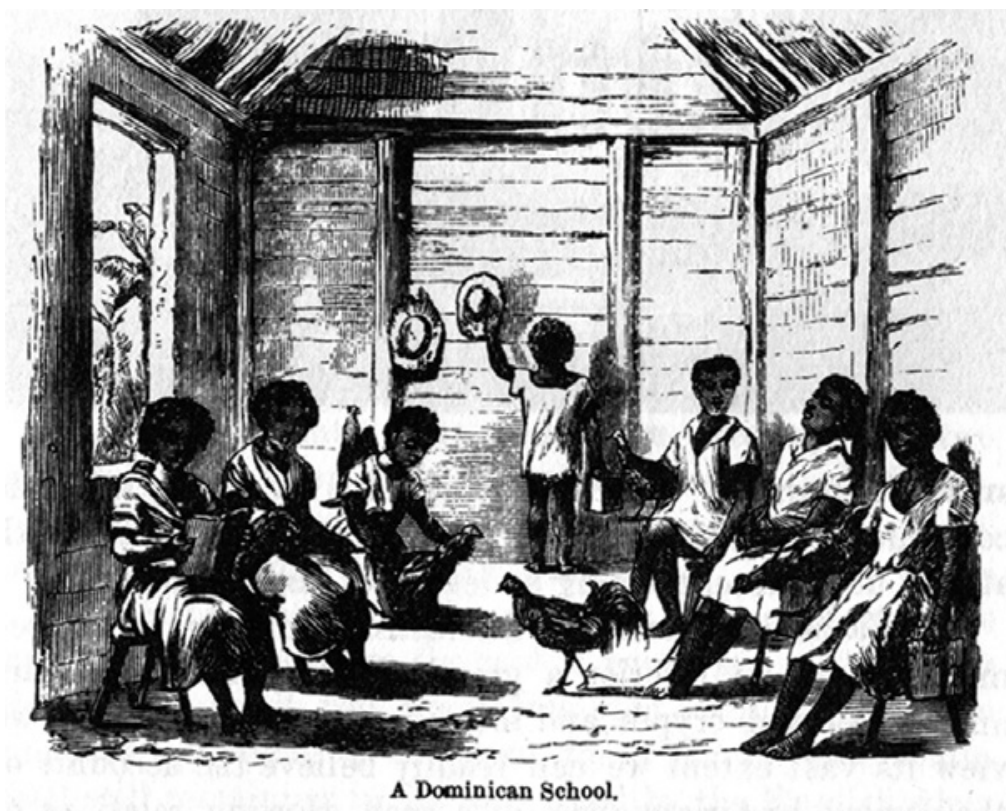

Fuente: Samuel Hazard. Santo Domingo, past and present; with a glance at Hayti (New York: Harper \& Brothers Publishers, 1873), 226.

Basta considerar los montos generalmente asignados a la escuela pública de localidades y secciones rurales para desprender que, necesariamente, tomaban lugar en situaciones donde el preceptor contaba con la "ventaja comparativa» de aportar el espacio para la escuela, pues a duras penas alcanzaba la pequeña subvención que entregaban los ayuntamientos o el Gobierno nacional más que para salario. Frente a los 40 o 50 pesos mensuales que se asignaba, en promedio, a un maestro en las ciudades, los de las secciones rurales percibían entre 8 y 12 pesos, comprometiéndose generalmente a recibir una matrícula municipal de hasta 20 infantes. ${ }^{23}$

${ }^{23}$ En la memoria del movimiento escolar de la provincia Espaillat en 1891, puede leerse: «de los planteles de enseñanza que existen en esta cabecera son 16; los últimos 9 son en los campos: cada uno está subvencionado con la exigua suma de ocho pesos que se pagan de los proventos municipales». «Memoria que dirije el gobernador de la Provincia Espaillat al ciudadano ministro de lo Interior y Policía» citado en González, Documentos para la historia, 360. 
La gradual extensión de la escuela pública a las secciones rurales durante el gobierno del general Cáceres, configuró las típicas dinámicas de desarrollo descritas un lustro después por los inspectores del Servicio Nacional de Instrucción Pública (SNIP), organismo reformador creado por las fuerzas de ocupación en 1918. Las casi 200 escuelas rurales creadas entre 1907 y 1916 se constituyeron en el espacio domiciliar de personas que tomaron el encargo de enseñar a núcleos de niños visados por las instancias de poder local (munícipes, gobernadores) y nacional (presidentes de la república), configurando el sistema de estructuras espaciales, de relaciones de poder y genealogía y de prácticas de escolarización que se propondrían afectar las reformas educacionales decretadas por la Ocupación. ${ }^{24}$

Como veremos a continuación, en el ocaso de la escuela-aposento operaría una compleja rearticulación de relaciones de poder y genealogía.

\section{HACIA LA ESCUELA «PRESIDENTE TRUJILLO»: LA OCUPACIÓN NORTEAMERICANA Y LA REFORMA ESCOLAR, 1918-1924}

Establecer public school systems se erigió en leit motiv de las administraciones militares norteamericanas en las Antillas, convirtiéndose en argumento importante del discurso que pretendió legitimarlas.

Conectado con el presunto interés por el auto-gobierno de los pueblos de las cuatro sociedades (self government, y su prerrequisito alfabetizador), el establecimiento y construcción de esos sistemas operó sobre la

\footnotetext{
${ }^{24}$ El renombrado político Juan Bosch, plasmó detalles de la escuela-aposento en un relato sobre su infancia en campos de la común de La Vega. Dice Bosch: «Entre un espeso palmar [...] estaba el bohío que escogieron para local. Era bajito, de tablas de palma, con cobija de yaguas y piso de tierra [...] A aquel bohío fue la maestra con su familia [...] El salón de clases [...] era la primera habitación, que tendría a lo sumo tres metros de largo por dos de ancho. Una puerta minúscula daba al comedor y otra brumosa, eternamente oscura, con la litografía de un santo clavada en el centro, abría paso al aposento [...] Al entrar dábamos los buenos días y besábamos a la maestra. Después nos arrodillábamos para saludar al padre de la "señorita Panchita" un viejo paralítico, pequeño, flacucho, y amarillo [...] Aprendimos bien poca cosa en la escuelita rural [...] pero ella fue en mi como la tala en el monte tupido que el campesino escoge para "fundo". Además había algunas enseñanzas que no están en los libros, ni en las palabras ni en los programas escolares, y que no he encontrado otra vez: el porte distinguido de Panchita, el obstinado silencio del paralítico, la humildad que nos metieron en el cuerpo la voz suave de la maestra y el obligado saludo de rodilla». Juan Bosch, «Una escuela rural hace veinte años», Revista de Educación, 27 (1935): 70-73.
} 
base de una crítica a las estructuras educacionales locales (en perspectiva del ocupante, herencia del funesto legado hispánico en Cuba y Puerto Rico y del fracaso administrativo de los fallidos Estados nacionales haitiano y dominicano), dando lugar a la formación de un discurso de contrastes y comparaciones culturales entre los sistemas escolares antillanos y el sistema norteamericano que impregnaría, principalmente en el gran público norteamericano, representaciones de sentido común sobre el atraso escolar de las Antillas.

La formación del discurso norteamericano sobre el sistema de escuela pública antillano cobró impulso a partir de 1898, con la colonización de Cuba y Puerto Rico. a través de un abigarrado conjunto de actores que iban desde el personal militar de todo rango hasta la intelectualidad planificadora de los gobiernos de ocupación, y permeando los medios de comunicación norteamericanos y locales que glosaron los avances civilizatorios obtenidos en la empresa de edificar sistemas de escuela pública en las sociedades ocupadas.

Decía en 1899 el titular del Consejo Insular de Educación de Puerto Rico:

Bajo el régimen español, el costo del sistema de escuelas públicas en la isla era mayor que el costo de las escuelas públicas de Maine, Missouri o Virginia [...] pero esos fondos eran tan irracionalmente gastados que cualquier americano inteligente podía viajar por la isla sin percatarse de que existía un sistema de escuelas públicas [...] Esos fondos no proporcionaron un solo edificio escolar $[\ldots]$ no equiparon ningún aula con mobiliario o útiles modernos, no proveyeron el menor vestigio de una base material [...] Las escuelas se alojaban en los domicilios de los maestros, entregando el municipio a cada maestro una pequeña suma para renta del local además de su salario. ${ }^{25}$

En su descripción, Clark implica rasgos del sistema escolar público norteamericano: planteles estrictamente dedicados a la enseñanza; edificios de propiedad pública; aulas equipadas con mobiliario y libros de

\footnotetext{
${ }^{25}$ Victor Clark, "Report on Public Schools of Puerto Rico» en Report of the Major-General commanding the army, editor War Department, (Washington: Goverment Printing Office, 1899), 640-643.
} 
texto; eficiencia del gasto escolar, etc., estableciendo los ejes por los que invariantemente transitaría la crítica del desarrollo educacional en las cuatro sociedades ocupadas. ${ }^{26}$

Autonomizar la escuela, segregar su espacio de la imbricación con otras instituciones, fue labor general que emprendieron los gobiernos de ocupación. Según Lindsay, entre otros muchos cambios radicales, el sistema puertorriqueño requería «una norma que estableciese que la escuela deba estar completamente separada de la residencia del maestro o de la de cualquier otra familia», ${ }^{27}$ cosa que sería decretada en 1903 dando paso a un ambicioso plan de construcción de planteles públicos aislados, algo que ocurrió en mucho menor medida en las demás islas, si bien en éstas se popularizaron conceptualmente las nuevas Casas-Escuela, traducción directa del sustantivo inglés school house.

Además del importante e inédito proceso de centralización de las estructuras educacionales locales que facilitó, el discurso urdido por el contraste crítico de la escuela antillana con el sistema de escuela pública norteamericano concretó varios alcances genéricos en esas sociedades. ${ }^{28}$

Uno, esencial, consistió en la transformación del antiguo espacio escolar público, que fue segregado de las instituciones sociales con que se articulaba, para erigírselo como espacio aislado, prevalentemente propiedad del Estado nacional. Típicamente, la implantación norteamericana promovió la construcción de locales aislados de propiedad públi-

\footnotetext{
${ }^{26}$ Respecto de Haití el general Cole señaló «La escuela nacional apenas existía [...] El Estado no era propietario de los planteles, sino que los rentaba. Inspeccioné una escuela [...] estaba construida con barro, y cuando entré en ella me di cuenta de que se trataba de una pocilga [...] nunca pudo habérsela ocupado en ningún sentido, modo o forma como plantel escolar, empero el gobierno pagaba por ella». United States Senate, Inquiry into the Occupation and Administration of Haiti and Santo Domingo (Washington: Government Printing Office, 1921), 87.

${ }^{27}$ Samuel Lindsay, «Inauguration of the American School System in Porto Rico», en Report of the Commissioner of Education for the year ending june 30, 1905, editor Comissioner of Education of Porto Rico (Washington: Government Printing Office, 1907), 301.

${ }^{28}$ Con excepción de Haití, donde el ocupante no controló directamente el sistema escolar, en las tres sociedades restantes las políticas de ocupación fueron esencialmente centralizadoras. Ver: Julian Go, «Chains of Empire, Projects of State: Political Education and U.S. Colonial Rule in Puerto Rico and the Philippines», Comparative Studies in Society and History, 42 (2), (2000): 333-362; Erwin Epstein, (1987), «The Peril of Paternalism: The Imposition of Education on Cuba by the United States», American Journal of Education, 96 (1): 1-23; Leon D. Pamphile, Clash of Cultures. America's educational strategies in occupied Haiti, 1915-1934 (Maryland: University Press of America, 2008); Angulo, Empire and Education.
} 
ca. Con alcances que variaron según el país, los gobiernos de ocupación estimularon la edificación de grandes inmuebles escolares, dotados de graduación y de estándares de higienismo, demostrativos de la epistemología con que propiamente nacía en esas sociedades el Estado Docente. Una nueva arquitectura escolar progresó en las distintas Antillas mediante la construcción directa, la nacionalización y adaptación de inmuebles o, como en la República Dominicana, mediante la creación de asociaciones de carácter civil que lo erigían para cederlo a la causa del Estado educador. ${ }^{29}$

Un aspecto trascendente del movimiento por la autonomización del espacio escolar resultó serlo la disolución de los entramados micropolíticos que ataban la escuela al ámbito domiciliar, en la imbricación que ello tenía con otras instituciones sociales, como el clientelismo político y las luchas por el control de dineros y cargos destinados a la escuela en ayuntamientos y comunes. Los reportes de inspección del SNIP de los años 1918-1920 son ricos en imágenes ilustrativas de las formas cotidianas de circulación del poder y el influjo local, desde la decisión de a quién otorgar el cargo de maestro de escuela; o a quien alquilar el local y cuanto pagar por él (ámbitos expresivos de meras simpatías e influjos) hasta la repartición partidaria de cargos, pasando por el uso patrimonial de las fuentes locales del fomento escolar. Una compleja micropolítica local modelaba el espacio escolar atándolo a sus lógicas de reproducción. Por ello, su transformación implicó combatir sus entramados.

Fue en escuelas del campo puertoplateño donde emergieron los primeros reportes diagnósticos sobre los límites que erigía la escuela-aposento para la reforma del sistema de enseñanza que deseaban implantar las fuerzas de Ocupación en «bien» de la vida dominicana.

En octubre de 1918, casi al cumplirse el segundo año de Ocupación militar, un Inspector de escuelas describía a su superior los obstáculos que hallaba en la empresa de elevar la calidad del servicio de enseñanza en las distantes secciones rurales fronterizas. Días antes se había decreta-

${ }^{29}$ Gratuidad y equidad fueron otros dos rasgos que también se transformaron, tanto en el sentido de que la relación con la escuela fuese paulatinamente convirtiéndose en una relación no dineraria, como en el de la relación sexualmente indiferenciada que comienza a definir al currículum, a las aulas y al cuerpo docente. En una relación siempre problemática con los contextos culturales locales, la escuela pública trató de ser libre, gratuita y coeducativa, ideal en el que el poder interventor tuvo ciertamente que negociar sus normativas, pero que avanzó importantemente durante estos procesos. 
do la Enseñanza Rudimentaria y el cuerpo de Inspección del recién creado Servicio Nacional de Instrucción Pública diagnosticaba febrilmente la idoneidad del ejército docente para aplicarla. Decía el Inspector:

El personal docente de algunas de las escuelas rurales de mi Distrito no tiene suficiente capacidad intelectual para llenar bien su cometido; pero es muy difícil reemplazar a algunos maestros porque las escuelas funcionan en enramadas anexas a las casas que ellos habitan y para poder nombrar otros es necesario construir antes locales independientes para las escuelas rurales. ${ }^{30}$

El límite que erigía a la calidad general del cuerpo enseñante la dependencia de espacios escolares propiedad de los maestros en servicio no era privativo de aquella remota región fronteriza. Desde espacios relativamente modernos, como los campos de Puerto Plata, otro Inspector transmitía por esos días un diagnóstico similar, al observar que los todos los locales «pertenecen, cuando no a los directores, a una persona familiarizada con éstos», hecho que hacía concluir que, para mejorar la calidad del servicio, "o se cierran temporalmente las escuelas donde se cambie o sea necesario cambiar al Director, o se fabrican locales adecuados cuanto antes para que el cambio pueda verificarse». ${ }^{31}$

De inicio, la reforma al currículo rural impulsada por la Ocupación topó con el escollo de un sistema de escuelas rurales fundado, en gran medida, en la escuela-aposento. El común de los Inspectores creía necesario retirar del servicio al gran número de maestros incapaces de aplicar los nuevos programas de estudio, pero no podía hacerlo por depender el servicio del espacio poseído por éstos. Como señalaban, había dos alternativas: o se cerraban escuelas en manos de maestros incapaces, o se procedía a construir primero los espacios que servirían luego maestros mejor formados.

Como clamaban los inspectores, la escuela no podía cambiar porque se hallaba alojada en espacios que pertenecían a los directores (que, en aquellas típicas escuelas unitarias del tornar al siglo $\mathrm{xx}$, eran directamente los maestros), que generalmente accedían al cargo por vínculos con la política

\footnotetext{
${ }^{30}$ Inspector del 32 Distrito Escolar, «Informe», octubre de 1918, Justicia e Instrucción Pública, legajo 682, AGN.

${ }^{31}$ José Francisco Camarena, «Informe», diciembre de 1918, Justicia e Instrucción Pública, legajo 682, AGN.
} 
local, provincial o nacional y no por trayectorias y méritos profesionales. La escuela pública de los campos se hallaba profundamente influida por la política partidaria que la había convertido en bien de intercambio, fuese porque se otorgaba el cargo de maestro a personas carentes de esa formación, pero que eran adherentes políticos locales, fuese porque se perseguía beneficiarlas con el otorgamiento de los distintos tipos de subsidio a la enseñanza que contemplaban los ordenamientos vigentes.

En la mirada del coronel Rufus H. Lane - administrador de la reforma del sistema de enseñanza-, una perniciosa dinámica de prebendarismo político se hallaba en el origen de la pobre calidad general de la escuela dominicana "Cualquiera en mala situación, pero con amigos políticamente influyentes, abría una escuela privada para inmediatamente solicitar subsidio al gobierno nacional o municipal, o a ambos [...] el clamor por vivir del erario público era impresionante». ${ }^{32}$

Tráfico de cargos, influjo de partidarismos, control de flujos de excedente, etc., constituirían los aspectos que combatirían las políticas de reforma educacional de la Ocupación. Como veremos a continuación, la naturaleza de esos límites no era solo espacial, ni podía vencerse con la mera construcción de espacios aislados de propiedad pública para uso exclusivo de la escuela. Vencerlos en aras de la modernización deseada requeriría desarticular la cadena de relaciones de poder y genealogía que los sustentaban.

\section{La reforma escolar norteamericana y el medio rural}

Aunque la ocupación fue proclamada un 29 de noviembre de 1916, la política de reforma educacional comenzó a desarrollarse un año más tarde. En el interín, una Comisión de civiles dominicanos designada por el Gobernador Militar Harry. S. Knapp laboró en su diseño. ${ }^{33}$

\footnotetext{
${ }^{32}$ Rufus Lane, "Civil Government in Santo Domingo in the Early Days of Military Occupation», The Marine Corps Gazette, 7 (2), (1922): 143.

${ }^{33}$ Esa Comisión representó la contraparte local de la política, circunstancia siempre presente en las ocupaciones, que invariantemente hallaron fracciones intelectualmente proclives a sus ideas o políticamente sagaces para aprovechar la coyuntura en términos de poder. Formada por conspicuos dominicanos, representantes de fuerzas todavía por ser políticamente comprendidas, la Comisión fue presidida por Julio Ortega Frier, abogado graduado de la Universidad de Ohio, que constituyó el interlocutor apto para traducir la apropiación cultural del modelo.
} 
La ocupación diseñó una serie de mecanismos de implantación de la reforma escolar. En esencia, éstos produjeron a las masas como sujeto escolar, controlaron y encuadraron al ejército docente como agente al servicio del Estado, crearon un espacio escolar de propiedad pública y legitimaron plenamente el control total del Estado sobre la transmisión curricular. Junto con intelectuales y fracciones políticas dominicanas que se apropiaron del proceso, la ocupación hizo emerger el nuevo Estado Docente mediante Órdenes Ejecutivas no sometidas a escrutinio civil, como la Ley de Instrucción Obligatoria de finales de 1917 y los trascendentes ordenamientos sobre la enseñanza pública y su dirección contemplados en la Orden N. ${ }^{\circ} 145$ de abril de 1918. Otros dispositivos legales fueron específicamente diseñados para modelar la escuela pública rural, en especial la Orden N. ${ }^{o} 86$ sobre Enseñanza Rudimentaria y la N. ${ }^{\circ} 1$ sobre establecimiento de Sociedades Populares de Educación. ${ }^{34}$

Las reformas calaron profundamente en la lógica precedente del sistema de escuela pública general dominicano, sentando bases para la emergencia y futura ampliación de un sistema de enseñanza nacional centralizado por el Estado y, con ello, para el alumbramiento de lo que podía propiamente llamarse Estado Docente en su historia. En el mundo rural su impacto fue muy importante, no solo por la creación de mecanismos que obligaron a los planteles de los campos a salir de los usuales espacios domiciliares en que se alojaban, sino porque entrañó una relevante exacción de fuentes de poder del nivel municipal en favor del Estado central, cosa que venía intentando hacer desde 1915 el Código de Educación Común, que postuló la centralización de ciertos aspectos del sistema de enseñanza, levantando extendidas resistencias políticas y culturales en ayuntamientos y comunes del país, que contuvieron la intromisión del centro ilustrado en sus potestades jurisdiccionales tradicionales, pero que cedieron finalmente ante el poder militar externo. ${ }^{35}$

La autonomía que había caracterizado la gestión de la enseñanza pública por parte de ayuntamientos y gobiernos provinciales (en materia, por ejemplo, de definición y asignación del gasto escolar y de selección

\footnotetext{
${ }^{34}$ Secretaría de Justicia e Instrucción Pública (SJIP), «Orden N. ${ }^{\circ} 86 »$, Listín Diario (Santo Domingo), 5 de octubre de 1918; SJIP, "Orden General N. . 1», Listín Diario (Santo Domingo), 4 de abril de 1919.

${ }^{35}$ El Código de Educación Común fue aprobado en 1915, siendo derogado en 1918 por el Gobierno de Ocupación. Representa la más acabada pieza programática del sistema de escuela pública generada por los discípulos de la Normal hostosiana. Su autor fue el Dr. Arístides Fiallo Cabral.
} 
del personal dirigente de los planteles, entre otras aspectos), se vio afectada por la creciente centralización del sistema que comenzó a operar meses antes de la promulgación de la trascendental Orden Ejecutiva N. ${ }^{\circ} 145$ de abril de $1918 .^{36}$

En septiembre de 1917, la Orden N. 1 del recién designado Encargado del Departamento de Justicia e Instrucción Pública por el Gobierno Militar de Santo Domingo, coronel Rufus H. Lane, comenzó a limitarla al subordinar las designaciones de cargos docentes a la autorización del Departamento, hecho que preludiaba la creciente centralización de la enseñanza que coordinaría más tarde el Servicio Nacional de Instrucción Pública. ${ }^{37}$ Frases como la del intendente Dubeau ("el Intendente aquí es una irrisión»), reveladoras de la puja por el control de las designaciones docentes entre un centro ilustrado y una periferia presta a impedir el perfeccionamiento pedagógico de la escuela en aras de la componenda política y del beneficio patrimonialista, desaparecerían de los papeles del SNIP de los años 1918-1922, indicándonos que el control sobre el nivel local triunfó, al menos momentáneamente. ${ }^{38}$

También en abril de 1918, la Orden Ejecutiva N. 146 asestaba un nuevo golpe a los circuitos de poder de ayuntamientos y comunes, al precisar la tasa y el modo de recaudación de los impuestos municipales dedicados al fomento educativo. En cuanto a la primera, la orden no fijaba nada radicalmente diferente de lo que postulaba el viejo Código

\footnotetext{
${ }^{36}$ Las cinco leyes decretadas por la orden 145 se basaban en las recomendaciones de la Comisión de Educación. La Ley Orgánica de Enseñanza Pública y la Ley para la Dirección de la Enseñanza Pública eran las más relevantes, pues daban paso a la centralización administrativa y curricular de un sistema esencialmente basado en el esfuerzo disperso de los Ayuntamientos. Aunadas a la Ley de Instrucción Obligatoria, dieron cuerpo al sistema de ordenamientos sobre enseñanza que rigió durante la ocupación. Gobierno Militar, «Orden Ejecutiva 114», Listín Diario (Santo Domingo), 12 de enero de 1918; Gobierno Militar, «Orden Ejecutiva 145», Listín Diario (Santo Domingo), 18 de abril de 1918. ${ }^{37}$ SJIP, «Orden del Departamento de Instrucción Pública», Listín Diario (Santo Domingo), 12 de septiembre de 1917. Días después, otra orden instauraba estructuras de obediencia burocrática inflexibles con quienes hiciesen llegar influjos de orden político o religioso a la escuela. SJIP, «Orden N. ${ }^{\circ} 10 »$, Listín Diario (Santo Domingo), 4 de octubre de 1917.

${ }^{38}$ Tras la desocupación, con el retorno de los viejos caudillos políticos al poder, el control de la política local tendería a relajarse. «Urge devolver a los Intendentes e Inspectores la plenitud de sus atribuciones selectivas en lo que respecta al proveimiento de vacantes del servicio docente y sustraer definitivamente las oficinas escolares y las escuelas de la acción nociva y disolvente del politiqueo menudo. Deben ser las autoridades escolares [...] quienes recomienden al Poder Ejecutivo los candidatos [...] para los cargos vacantes y no las juntas de partidos políticos», decía un Inspector en 1926. Inspector 34ava. zona escolar, «Informe», agosto de 1926, Justicia e Instrucción Pública, legajo 10, AGN.
} 
de Educación Común derogado; no así en cuanto al modo de ejercer los recursos fiscales, que en lo sucesivo serían centralizados por la Secretaría de Justicia e Instrucción Pública, desde donde volverían a las tesorerías locales para efectuar los pagos. ${ }^{39}$

La desarticulación del control local sobre el fomento educativo se vio potenciada por la constitución paralela de un espacio escolar de propiedad estatal, producto tanto de la construcción de casas-escuelas con cargo al erario nacional (cosa que preponderantemente ocurrió en las ciudades) como del encuadramiento y exacción del esfuerzo de la comunidad campesina por establecerlo y cederlo graciosamente al Estado.

Las Sociedades Populares de Educación creadas en la primavera de 1919 tuvieron ese sentido: asociaciones de vecinos dispuestas a establecer la escuela en rústicos inmuebles rurales de propiedad pública. Las localidades carentes de escuela debían organizarlas como preámbulo de su solicitud al Servicio Nacional de Instrucción Pública, así como éstas debían constituirse en torno de los planteles de antaño establecidos. Fue su trabajo el que esencialmente hizo aflorar el espacio escolar público en la campiña dominicana, como también lo hizo en otras experiencias internacionales de centralización bajo la égida del Estado.

Las Sociedades se integraban preponderantemente con guardianes de niños inscritos en el plantel, condicionando el ingreso de no-guardianes a vista pública en Asamblea. De modo interesante, inspectores y maestros del SNIP tenían un poder sobre las decisiones de las juntas directivas de las Sociedades que subordinaba en sus Estatutos a síndicos y alcaldes pedáneos (representantes del poder político local), a quienes se daba voto en caso de ausencia del agente burocrático del Servicio. Las Sociedades debían proveer los terrenos y edificios para el establecimiento de la escuelas, encargándose de su erección (bajo normas provistas por el Estado) y de su mantenimiento, pudiendo arbitrar fondos dinerarios para la consecución de esos fines, pero incapacitada de «solicitar para el efecto fondos fiscales o municipales».

Un pálido sentido de creación de instituciones cívicas para el self government podría imputársele al diseño de las Sociedades Populares de Educación, que más que comunidades de deliberación tendieron a

\footnotetext{
${ }^{39}$ Gobierno Militar, «Orden Ejecutiva N. ${ }^{\circ}$ 146», Listín Diario (Santo Domingo), 20 de abril de 1918.
} 
constituirse en núcleos de campesinos tributarios del creciente poder central. Muestra de que el ocupante no las imaginaba como comunidades de opinión a ser ilustradas (cosa que hubiese implicado, como en los EE.UU., cierta prédica por el laicismo, por la equidad de género, por el supremo deber de la ilustración), las Sociedades estaban autorizadas - previa entrega de los locales- para:

[...] determinar si la escuela debe ser mixta, o si los alumnos deben ser divididos de tal forma que los varones asistan durante uno de los períodos y las hembras durante el otro [...] determinar si la dirección de la escuela debe ser asignada a un hombre o a una mujer [...] fijar las épocas del año en que la escuela deba disfrutar de los períodos de vacaciones [...] fijar la hora en que deba comenzar cada período de trabajo escolar. ${ }^{40}$

A pesar de que no se las concibió para aplicar una agenda de ideas progresivas respecto al auto-gobierno, la coeducación o el laicismo, quedaron descritas para la posteridad del siguiente modo:

En los distritos rurales se hizo el experimento de formar sociedades de padres que tenían en cierta medida el control de detalles en relación con la escuela [...] Estas sociedades erigían el edificio escolar [...] Estas sociedades trabajaron con entusiasmo y bien, y podrían haber sido consideradas como inicios de la propagación del gobierno democrático en el país. ${ }^{41}$

No existe registro del número de Sociedades creadas en el lapso 19191920, ni estimación fundada de su contribución a la formación del sistema estatal de escuelas rurales. Basado en fuentes del Gobierno Militar, Angulo señala que cientos de ellas fueron creadas en el lapso 1919-1924, contribuyendo a la expansión del naciente Servicio Nacional de Instrucción Pública con la cesión de unos 300 planteles (lo que representaba casi

\footnotetext{
${ }^{40}$ SJIP, «Orden General N. ${ }^{\circ}$ 1», Listín Diario (Santo Domingo), 4 de abril de 1919.

${ }^{41}$ Lane, "Civil Government in Santo Domingo», 145.
} 
la mitad de las 647 escuelas rurales que Snowden imputaba en 1920 a la ocupación $)^{42}$ bajo un esquema de exacción de trabajo impago. ${ }^{43}$

Sin duda, las Sociedades contribuyeron de modo importante al esfuerzo escolar del gobierno militar, entregando gratuitamente pequeños edificios rurales que permitieron economías en alquiler y mantenimiento de locales. Sin embargo, su papel como mecanismo de apoyo a la centralización del sistema en curso deberá valorarse con método a partir de fuentes operativas del SNIP, dado que es posible captar fenómenos que deben todavía ser sistematizados.

El primero alude a la duración de su acción, pues las Sociedades emergen y dan mucho de qué hablar durante la muy específica coyuntura del bonancible presupuesto de los ciclos escolares 1919/20, 1920/21. De constituir en esos años un ítem informativo regular en los reportes de inspección, poco sigue mencionándoselas en los que se generan entre 1922 y 1924.

También debe valorarse el carácter de su contribución al proceso de creación de un espacio escolar público segregado, pues aunque los reportes del lapso 1919-1921 revelan que su papel no siempre tuvo fines constructivos, pues algunas de ellas operaron en conexión con la gestión de fondos civiles para seguir alquilando locales de escuela, o gestionando inmuebles de propiedad municipal preexistentes. Esos reportes dejan también ver que no todas las Sociedades que se establecieron recibirían el servicio escolar, particularmente en el marco de las severas restricciones financieras que afloraron a partir del ciclo 1921/22. Así, de las 17 Sociedades Populares de Educación que reportaba en la común de Guayubín el inspector Juan Tomás Lithgow a fines de 1919, sólo siete procedieron con la construcción de edificios. Las restantes se abocaron a la habilitación de planteles de propiedad privada y municipal, o a sostener con su propio peculio el alquiler de locales. ${ }^{44}$

\footnotetext{
${ }^{42}$ US Military Government of Santo Domingo, Santo Domingo: Its Past and Its Present Condition (Santo Domingo: s.e., 1920).

${ }^{43}$ Angulo, Empire and Education, 83.

${ }^{44}$ Inspector 35 Distrito Escolar, «Informe», diciembre de 1919, Justicia e Instrucción Pública, Legajo $1 / 734$, AGN.
} 
La emergencia de Sociedades revela también diferencias regionales posiblemente ligadas con el desarrollo local de la cultura escolar. En este sentido, tendieron a surgir homogéneamente en comunes del llamado Valle del Cibao, donde la escuela rural tenía una historia más larga, que en zonas de nueva escolarización como la frontera con Haití o las llanuras azucareras del Este. El primer tipo de comunes muestra la creación de numerosas sociedades; en las segundas su mención es menos frecuente. La presencia histórica de una cultura escolar pudo constituir un elemento decisivo en la formación de Sociedades Populares de Educación, que rápidamente movilizasen el esfuerzo local en aras de la continuidad de un servicio educativo cada vez más perturbado por la estrechez económica. ${ }^{45}$ Con todo, en comunes de vieja escolarización como Moca, en el centro del país, sólo la mitad de las escuelas rurales contaban con Sociedad Popular de Educación en 1921.

Ciertos incidentes revelan procesos de resistencia a su creación y a la noción de que era deber del pueblo dominicano sumar su esfuerzo a la expansión escolar del SNIP. Tal pareció el caso de una denuncia investigada en la común de Guayubín, según la cual el Sr. Carlos Rojas (empleado del SNIP en la cercana ciudad de Moca) había venido afirmando que los de Guayubín eran "muy sonsos con estar contribuyendo para ayudar a construir casas-escuelas», pues en Moca el que estaba obligado a construir era «el Ayuntamiento [...] que él no permitía que las gentes de los campos contribuyeran para eso,» ${ }^{46}$ discurso que puede leerse como legitimidad del viejo orden escolar municipal y como repulsa a las diversas formas de exacción de trabajo impago impuestas por el Gobierno Militar al campesinado.

Así, con el concurso de mecanismos como las Sociedades Populares de Educación, la escisión del politiqueo que ataba la escuela al espacio domiciliar-privado y la intervención de las rentas municipales, la política de Ocupación alcanzó parcialmente a concretar el ideal de segregación del espacio escolar para su conversión en espacio de propiedad pública exclusivamente abocado a la enseñanza.

\footnotetext{
${ }^{45}$ La gran expansión de la Escuela Rudimentaria rural se vio abruptamente frenada en 1921 por el efecto combinado de la crisis de los precios del azúcar y el cambio del sistema fiscal que nutría el fomento escolar.

${ }^{46}$ Inspector 35 Distrito Escolar, «Informe», diciembre de 1919, Justicia e Instrucción Pública, Legajo 1/734, AGN.
} 
Los alcances de este logro a lo largo del campo dominicano son difíciles de precisar, pues en el turbulento período que condujo a la desocupación del país en 1924 y a la inestabilidad gubernativa que traerían las pugnas entre viejos caudillismos políticos por el control del Estado, el aparato escolar rural experimentó marcadas discontinuidades. Sin embargo, la reforma pudo aparentemente apropiarse y consolidar una plantilla importante de espacios para la escuela en secciones rurales a lo largo y ancho del país.

De las alrededor de 200 escuelas rurales que existían en 1915 a las 647 que anunciaba triunfalmente Snowden en 1920 ¿cuántas le fueron legadas por las Sociedades Populares?

Muchas, aunque lejos de serlo todas, como meridianamente lo mostraría la profundización de la política de centralización y ampliación del espacio escolar propiedad del Estado que desarrollaría la dictadura de Rafael L. Trujillo, "el Generalísimo» que sujetó la vida dominicana durante poco más de treinta años y en cuyo honor —más bien, por cuya progenitura - se vestiría la campiña dominicana de un nuevo espacio escolar, icónico y funcionalmente vinculado con el dominio despótico: la escuela "Presidente Trujillo».

\section{LA ESCUELA «PRESIDENTE TRUJILLO»Y EL ENCUADRAMIENTO SOCIAL DEL CAMPESINADO DOMINICANO, 1933-1944}

Fue nuevamente una primavera la que trajo cambios a la escuela rural pública del campo dominicano. En esta segunda ocasión -la primera había sido en 1919-, el cambio haría que el espacio escolar se implantase como institución emblemática de un régimen de dominación y como un aparato definidamente representantivo del Estado.

En marzo de 1931, la Ordenanza N. ${ }^{\circ} 193$ del Consejo Nacional de Educación dispuso el establecimiento de Asociaciones de Amigos de las Escuelas en todos los planteles rurales del país. Presentadas como otra de las geniales «innovaciones» que el Benefactor ensayaba en interés del pueblo dominicano, las nuevas Sociedades reeditaban las implantadas en días de la Ocupación militar norteamericana, si bien resurgían con ciertas mutaciones. 
Los organismos especificados por la ordenanza tendrían como fines primordiales el

cooperar al mejor éxito de la obra de la educación; ayudar al engrandecimiento moral y material de la escuela; estimular el entusiasmo del alumno por la propia escuela [...] lograr una mayor compenetración entre los padres y los maestros, y despertar la iniciativa privada en beneficio de la escuela dominicana. ${ }^{47}$

Sus socios serían los padres de los alumnos inscritos y los maestros del plantel, pudiendo admitir en Asamblea el ingreso personas ajenas al servicio en calidad de amigos. Cada socio debía libremente cotizar sumas que no excediesen un peso anual, pues «estas Asociaciones no deben [...] crear otras obligaciones que las que espontáneamente quiera imponerse el individuo». Una Junta Directiva, integrada por socios y maestros tendría voz y voto sobre los asuntos de la escuela, pudiendo participar, sólo con voz, otras personas interesadas, como el personal dirigente del sistema de enseñanza. El Director de la escuela sería siempre el asesor técnico de la Junta Directiva.

Frente a sus antecesoras, a quienes se reconocía jurisdicción en varios procesos de gestión escolar y pedagógica, las nuevas Asociaciones carecen de ella. El contraste entre la Orden N. 86 de 1919 y la moción del superintendente Max Henríquez Ureña aprobada como ordenanza por el Consejo Nacional de Educación en 1931 abre vías de reflexión.

Como fines, deberes, derechos y prácticas, el ordenamiento de 1919 es prolijo en la prescripción del modus operandi de las Sociedades Populares de Educación. Las Sociedades podrían crearlas los padres de los alumnos inscritos en el plantel tanto en localidades con escuela instalada como en aquellos lugares que careciesen de ella y existiese interés por su creación. Su fin esencial sería el de proveer «los locales y terrenos [...] necesarios para la escuela o las escuelas Rudimentarias del lugar» de acuerdo a criterios que respondan "a las condiciones que sean requeridas en edificios y terrenos para esta clase de escuelas». La Sociedad «mantendrá dichos edificios y terrenos en completo estado de limpieza y buen orden», pudiendo administrar fondos pero no pudiendo solicitar para el

\footnotetext{
${ }^{47}$ «Asociaciones de Amigos de las Escuelas», Revista de Educación, 3 (11), (1931): 51.
} 
efecto «fondos fiscales o municipales». Las Sociedades constituidas en localidades sin escuela podrán solicitar el envío de un maestro pagado con fondos público cuando provean los edificios y terrenos y cuando aseguren la inscripción de 40 niños.

Cumplidos esos deberes, las Sociedades tendrían derecho a decidir, como fue señalado, si la escuela era mixta o segregada, si el maestro era hombre o mujer, las épocas del receso vacacional durante el año y el horario de clases. Las Asambleas de asociados tomarían lugar en la escuela, pudiendo ser empleada ésta como lugar de reunión "para que el maestro les lea obras útiles» o para leer quienes supieran hacerlo. La Sociedades serían dirigidas por un Presidente (padre de familia) fungiendo como su Secretario el maestro. Las decisiones habrían de transmitirse al Inspector escolar, quien podrían solicitar al Consejo Nacional de Educación su veto.

Frente a la Orden N. ${ }^{\circ}$ 86, la moción del superintendente Henríquez Ureña es parca en el señalamiento de deberes, derechos y formas de operación de las Asociaciones. Por principio, es omisa en la definición del orden de democracia y deliberación que pálidamente especificaba su antecesora, guardando también silencio respecto de su intervención en aspectos de género y gestión del plantel. ${ }^{48}$

También se elude la mención del deber de las Asociaciones de aportar edificios y terrenos para la escuela, cosa que el funcionariado trujillista tenía claro desde los inicios del régimen y que manifiestamente promovería desde mediados de $1933 .{ }^{49}$ En este sentido, podría pensarse que

\footnotetext{
${ }^{48}$ Una opinión crítica del año 1929 refleja la percepción que parecía presidir la visión del funcionariado: «Las Sociedades Populares de Educación tienen el deber de proporcionar el local para la Escuela del lugar. Es el único deber que la Orden de su creación les atribuye. En cambio, tienen el derecho [...] de hacer que el Director del plantel les lea y les escriba su correspondencia, les lea la prensa, les aconseje en sus asuntos, y en su calidad de entidad oficial, de determinar si la escuela debe ser mixta o no; si la dirección debe ser encomendada a un Hombre o a una Mujer; de fijar las horas de clase; de fijar los períodos de vacaciones [...] Sólo por exposición elevada ante el Consejo Nacional de Educación, puede un Inspector de Instrucción Pública hacer oposición a cualquier... acuerdo de ellos por absurdo que sea... Ha sido muy peligroso darle atribuciones pedagógicas a gente en su mayoría analfabeta». Revista de Educación, 1 (5), (1929): 473.

${ }^{49}$ Escribía el superintendente Jiménez en 1930: «En cuanto a los locales para las escuelas rudimentarias se puede conseguir que Inspectores de Instrucción Pública y Síndicos Municipales, de común acuerdo, reúnan a los vecinos de las diferentes secciones rurales en donde hoy escuelas, para hacer, por la vía persuasiva, que estos construyan el local dando cada uno lo que pueda [...] donándolo después al Estado mediante acto notarial». Tres años después, el entonces superintendente Pedro
} 
Henríquez procurase una redacción que evitase el recuerdo de los mecanismos de exacción de trabajo impago que pesaron sobre el campesinado durante la Ocupación, si bien el régimen trujillista recurriría a ellos de modo más extendido.

Lo que si quedaba claro en la ordenanza es que tales Asociaciones emergerían por el acto demiúrgico del personal dirigente (maestros e inspectores), que su creación sería asunto «de utilidad pública» y que había llegado la hora de «estimular por todos los medios la iniciativa privada en obsequio de nuestras escuelas. Desechemos la tradicional falacia [...] de que el Estado lo debe hacer todo. Ningún Estado hace más de lo que puede, y además hay muchas iniciativas que deben ser exclusivas del orden privado». .0

En esa lógica de pérdida de jurisdicción de la sociedad local en favor de su traslado al esquema paternalista se anuda parte de la trama representó la inserción del eventualmente poderosísimo Partido Dominicano en las dinámicas escolares rurales a mediados de 1933. En abril de ese año, cuando la crisis del sector externo se resentía de modo más profundo, cuando quizás era poco el apoyo que habían logrado, hasta la fecha, negociar con los empobrecidos agricultores Inspectores y maestros del servicio público, Trujillo solicitó al Partido Dominicano (del cual era Presidente) lanzarse a una campaña nacional por la construcción de 1000 Casas-Escuela para alojar los planteles rurales. ${ }^{51}$

Así, en la fragua de las medidas de emergencia con que se había inaugurado su régimen, que conllevaron el establecimiento de una nueva gran alianza de signo paternalista - por no decir mesiánico- del trujillismo con el campesinado, nació la nueva escuela "Presidente Trujillo», espacio rural cedido por los campesinos para que el Estado concretase en

Henríquez Ureña giraba a sus inspectores la Circular 65 pidiéndoles informar «con absoluta exactitud en qué casos los padres de familia y guardianes de alumnos no dan el local que necesitan las escuelas rudimentarias [...] En estos casos, es indispensable hacer comprender a los vecinos que [...] será necesario trasladar la escuela a otro paraje donde los vecinos muestren más interés [...] Debe usted estudiar la manera de ir construyendo en cada lugar un local definitivo para la escuela rudimentaria. El terreno y la construcción que sobre él se haga, debe pasar a ser propiedad del Estado, poniéndose a nombre del Consejo Nacional de Educación». Ramón E Jiménez, julio de 1930, Justicia e Instrucción Pública, legajo 114951, AGN; Inspector 23avo distrito escolar, «Informe», abril de 1933, Justicia e Instrucción Pública, legajo 114380, AGN.

50 «Asociaciones de Amigos», Revista de Educación, 3 (11), (1931):50.

${ }^{51}$ Revista de Educación, 5 (20), (1933): 10. 
él no sólo la enseñanza pública sino un bien complejo esquema de rasgos despótico-corporativos.

A mediados del mismo año 1933, en lo que constituía una respuesta una circular de la Superintendencia (ocupada ahora por Pedro, el mayor de los hermanos Henríquez Ureña), el inspector Ortega reportaba:

Se ha obtenido el más lisonjero resultado con la campaña pro construcción de la casa-escuela rural «Presidente Trujillo» patriótica iniciativa del joven mandatario cuyo nombre ostentan estos locales sencillos en su construcción típica, pero verdaderos centros de cultura... con las casas-escuelas que se preparan en el otro Distrito habrá un conjunto de 60 a 70 casas-escuelas en la común de Santiago y probablemente 9 en la común de Peña. ${ }^{52}$

Como señalaba el inspector, las nuevas escuelas «Presidente Trujillo» eran sencillas construcciones típicas de la vida rural dominicana. El diseño oficial, la maqueta que se ponía en manos de los agentes del servicio para impulsar su edificación (ver imagen 2), las hacía aparecer como la característica vivienda campesina de madera, techada de guano, levantada sobre una planta rectangular de alrededor de 48 metros cuadrados.

El diseño superaba en dimensiones al tradicional espacio escolar rural, al menos al que se generó por las Sociedades Populares de Educación de los años veinte, cuya superficie prácticamente doblaba. ${ }^{53}$ Sin embargo, reeditaba sus rasgos como espacio de enseñanza, al postular un aula única en la que un maestro instruía simultáneamente a niños de distintas edades.

Con su bandera nacional al frente y con su huerto escolar y su palma real a cada lado, la imagen de la escuela «Presidente Trujillo» materializó en los campos el espacio emblemático del nuevo orden de dominación que entrañaría la dictadura de Rafael L. Trujillo.

\footnotetext{
${ }^{52}$ Inspector 23avo distrito escolar, «Informe», abril de 1933, Justicia e Instrucción Pública, legajo 114380, AGN.

${ }^{53}$ Un reporte sobre escuelas rudimentarias rurales de la común de Jánico revela planteles que promediaban 24 metros cuadrados de superficie. Justicia e Instrucción Pública, mayo 1918, expediente 1/686, AGN.
} 


\section{Maqueta de la nueva escuela rural dominicana «Presidente Trujillo» 1933}

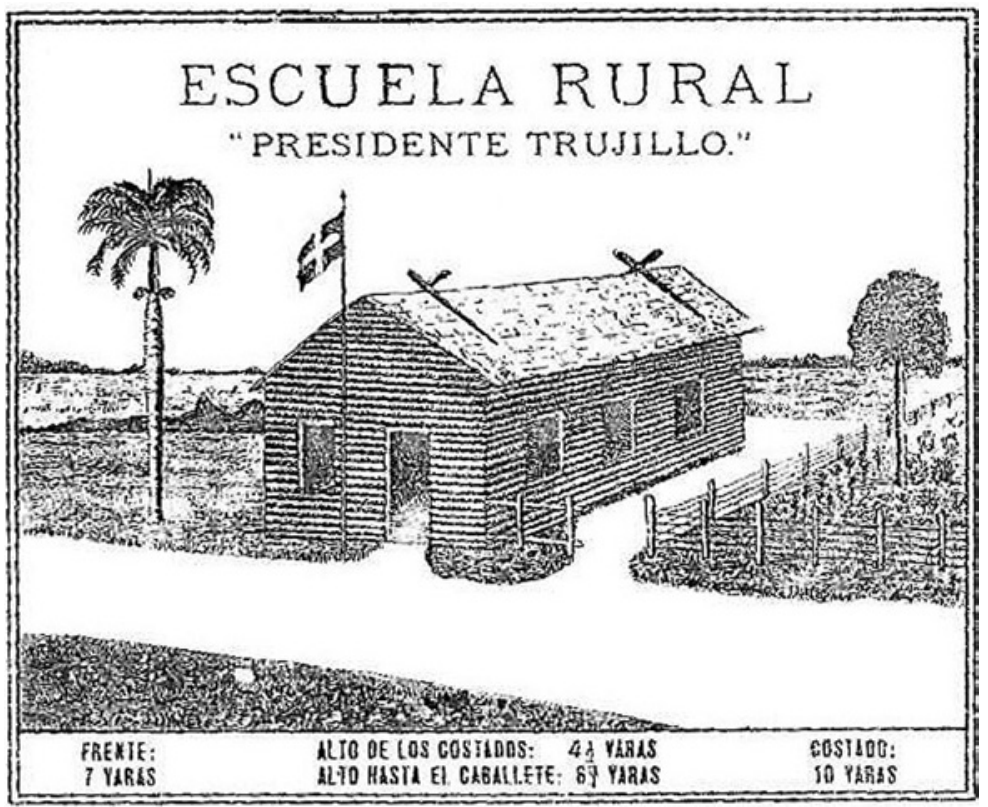

Fuente: Servicio Nacional de Instrucción Pública, Archivo General de la Nación.

Construida mayormente por el Partido Dominicano - oh reificación estatolátrica-, cuyo emblema era evocado por la estratégica "palmita», la nueva escuela comenzó a concretar el orden político-burocrático que controló la vida dominicana por décadas. Nacida del acto demiúrgico de los maestros, en sus locales sesionaron con frecuencia metódica las juntas locales del partido, en el marco de actos «político-sociales» dedicados al culto a la obra de quien más tarde devendría Benefactor de la Patria Nueva, Primer Maestro, Generalísimo, Jefe y todo los otro epítetos con que se conocería al tirano.

En tanto dispositivo institucional de propaganda y control que brindo conocimiento y poder social sobre la vida rural al régimen trujillista, la escuela rural «Presidente Trujillo» tuvo una trascendencia que ha recibido poca atención. ${ }^{54}$

\footnotetext{
${ }^{54}$ Juan Alfonseca, «Escolarización y dictadura. La escuela rural y el encuadramiento del campesinado en la República Dominicana (1930-1940) », Boletín del Archivo General de la Nación, 36 (130), (2011).
} 
Cerraremos nuestra discusión con lo que ésta nueva transmutación del espacio escolar supuso en cuanto a configuración de relaciones de poder y genealogía en el campo dominicano.

En primer término, la expansión del modelo «Presidente Trujillo» definitivamente sepultó a la escuela-aposento como espacio histórico, consolidando una planta institucional en poder del Estado como espacio segregado de enseñanza pública, labor que había tomado inicio durante la Ocupación norteamericana y que la dictadura sencilla aunque potentemente profundizó. Estimulado por la acción del propio Estado y del Partido Dominicano, esa creciente red de espacios institucionales acicateó la alianza en ciernes entre el trujillismo y las nuevas camadas de maestros normalistas que surgían en las ciudades, con lo cual — puede decirse- truncó la vieja micropolítica que ataba la escuela al maestro local y a sus vínculos interés. ${ }^{55}$

No por ello suprimió la micropolítica local en derredor de los planteles pueblerinos — que, en el interín del renovado ciclo caudillista abierto en 1924 por la desocupación del territorio por las fuerzas norteamericanas, tendió a rearticularse bajo otras formas, menos dependientes de maestros y espacios-aposento locales, pero profundamente atravesadas por el faccionalismo en la repartición prebendaría de cargos en el servicio escolar pueblerino.

En su pugna estratégica por desterrar el influjo de los viejos caudillos, el trujillismo fraguó en los campos nuevas alianzas, que articularon en los pueblos bloques integrados por el personal dirigente del servicio escolar (maestros e inspectores, agrónomos ocasionalmente) y representantes y activistas del partido del Estado en labores de movilización y encuadramiento político y cívico del campesinado a través del culto y el concurso con la obra del Jefe.

La nueva alianza no refundó los viejos lazos subsistentes de la escuela-aposento en el orden campirano, sino que los erradicó finalmente por

\footnotetext{
${ }^{55}$ Habría que distinguir etapas históricas en el movimiento normalista y en su inserción dentro del proceso más amplio de constitución del sistema de enseñanza pública dominicano. Entre el normalismo de viejo cuño, gestado en los años ochenta del XIX, imbuido de pedagogía y moral sociales hostosianas y el que tendió a establecer alianzas con la dictadura trujillista en ascenso existen distancias que es tarea pendiente analizar. Zeller ha sentado aspectos cardinales en esa evolución. Neici Zeller, Discursos y espacios femeninos en República Dominicana, 1880-1961 (Santo Domingo: Letra Gráfica, 2012).
} 
el convencimiento del nuevo funcionariado en insistir en la consolidación del sistema escolar sobre un modelo de institución aislada de propiedad del Estado (de jurisdicción cada vez más nacional, en este nuevo ciclo del proceso centralizador). En los campos, el trujillismo distribuyó cargos docentes a maestros egresados de las escuelas normales, que posiblemente fuesen oriundos de los pueblos donde enseñasen, pero que no vinculaban ya ni sus domicilios, ni sus procesos de interés con el erario local. Todo esto pasó a controlarlo la eventualmente potente Secretaría de Estado de Educación, Bellas Artes y Cultos. A los campos, iba el maestro en condición de intelectual orgánico del modelo dictatorial. A difundir, a encuadrar y poblar la mente del campesino en la Cartilla Cívica y en la exégesis de la obra patriótica del Benefactor. Por convicción o por amenaza, ese fue su papel y tuvo que cumplirlo.

Junto al elenco burocrático dirigente, el exhorto a la iniciativa privada hecho por la ordenanza relativa a las Sociedades de Amigos, operó como el canal propicio para la emergencia y articulación de nuevas alianzas cívicas de nivel local, como la que el obsequioso don Sabás Santana, rico agricultor de Las Lagunas, común de Moca, que ofrecía donar a la escuela 5 tareas de tierra, deseando «tener la satisfacción de que el Honorable Presidente Trujillo le dirigiera una carta congratulatoria», ${ }^{56}$ posiblemente con el fin de colocar en lugar visible, en la entonces naciente Era en que los retratos y los reconocimientos del Jefe se convertirían en preciado objeto de decoración de las viviendas, dando muestra a sus visitantes de profesión de fe. ${ }^{57}$

\section{EPÍlLOGO}

En el curso de los cien años analizados, el espacio escolar dominicano transitó del modelo de escuela-aposento — parcialmente público

\footnotetext{
${ }^{56}$ Inspector del 25avo Distrito Escolar, «Informe», 3 de diciembre 1935, Justicia e Instrucción Pública, legajo 28, AGN.

${ }^{57}$ Turits señala: «los esfuerzos de Trujillo por desarrollar un tipo de populismo rural [...] fueron mucho más sustanciales de lo que se ha asumido [...] el poder era ejercido [...] en constante negociación con las elites y en intercambios, aunque desiguales, con los sectores populares». Richard Turits, «The foundations of despotism. Agrarian reform, rural transformation, and Peasant-State compromise in Trujillo's Dominican Republic, 1930-1944», en Identity and struggle at the margins of the nation-state. The laboring peoples of Central America and the Hispanic Caribbean, editor Aviva Chomsky (Durham: Duke University Press, 1998), 293. (traducción nuestra).
} 
e integrado a otras instituciones sociales- al espacio escolar aislado, propiedad del Estado nacional docente, al que accedía gratuitamente el campesinado.

Hemos descrito a grandes rasgos una transmutación espacial y genealógica que afectó a la escuela pública de los campos del país, pero que afectó, igualmente, al resto del sistema escolar nacional pues se trató, ni más ni menos, que del parto histórico del sistema de escuela pública.

Genéricamente se ha aludido a órdenes de configuración de poder político y genealógico en el largo trabajo de parto institucional que supuso la transmutación de la escuela-aposento a la escuela «Presidente Trujillo» en la vida rural dominicana. Un orden de configuración y cambio en las relaciones sociales que daban vida al espacio escolar público ocurrió en la esfera del proceso histórico de centralización del poder que supuso - como en todas las latitudes- la formación del Estado nacional dominicano. Exacción de fuentes de poder de la esfera municipal en favor del Estado central (recursos para el fomento escolar, jurisdicción sobre la adjudicación de cargos en el servicio escolar, gobierno sobre el plantel escolar, etc.) constituyen los rasgos de una pugna que nos es familiar pues se editó invariantemente en la génesis del Estado docente de la modernidad. ${ }^{58}$ Vimos, en este tenor, a un Estado nacional haciéndose con el control de la renta local para el fomento de la escuela y haciéndose, de más en más, con el control de quienes enseñarían, donde se enseñaría y a quienes y a cambio de qué se les enseñaría. Instalándose en la vida pueblerina del hinterland dominicano por mediación de maestros e inspectores, el Estado nacional fue paulatinamente acrecentando sus jurisdicciones sobre la transmisión curricular.

Hemos delineado con menor detalle las aristas epistemológicas del combate que se libró en ese terreno concreto de la centralización y del control curricular o, al menos, hemos aludido de modo menos claro los proyectos de pedagogía instalados en esa pugna. Un posicionamiento central en ella se configuró en derredor del normalismo de cuño hostosiano y sus ideas sobre lo que debía ser la escuela y la educación del común cónsonas con los postulados de la pedagogía moderna. Fue el nor-

\footnotetext{
${ }^{58}$ Laurence Brockliss y Nicola Sheldon, «General Introduction», en Mass schooling and the limits of State Building, c. 1870-1930, editores Laurence Brockliss y Nicola Sheldon (Londres: Palgrave Macmillan, 2012).
} 
malismo hostosiano el que dio forma a una epistemología social sobre la escuela y al debate que lo enfrentó, desde luego, con los intereses locales que sustentaban la escuela-aposento, no sólo por su crítica técnico-pedagógica al espacio escolar constituido por dinámicas de circulación del poder local, sino por su oposición al influjo del politiqueo menudo en el reclutamiento docente.

La crónica de los debates de la intelectualidad hostosiana con las fuerzas que tendían a perpetuar la dinámica local que daba vida a la escuela-aposento puede rastrearse desde fines del XIX hasta los mismos días de la ocupación norteamericana, resultando una deuda historiográfica pendiente su investigación. Esos debates fueron formando el discurso de epistemología social que socavaría las bases del control local del fomento de la escuela-aposento pública en el medio rural (lo mismo que en el urbano) mediante el que se abrirían paso la descalificación pedagógica del docente empírico, la elevación del enseñante certificado, la crítica higienista a las condiciones del espacio escolar, la formulación del saber y la pedagogía adecuadas para la vida rural y, en suma, la intervención privilegiada del poder central del Estado nacional en la definición y control del proyecto de escolarización que, años más tarde, la Ocupación catalizaría concretándola gracias al definitivo poder de la mano militar.

En este sentido, existe cierta continuidad entre el ideario del sistema de escuela pública que requería la sociedad dominicana en mente de los hostosianos y los proyectos que acabarían entronizando luego las fuerzas ocupantes junto con la fracción doméstica que los conduciría. Aunque ciertos sectores de la intelectualidad formada en la Escuela Normal se enfrentarían políticamente con el ocupante, lo cierto es que no era difícil que consintiesen con éste en la implantación del proyecto de escuela pública bajo ideas-fuerza como el espacio aislado, de propiedad pública y acceso universal gratuito. El mismo Eugenio María de Hostos celebró rasgos del sistema estadounidense, así como lo hicieron también conspicuos discípulos suyos como Félix E. Mejía, Director General de Enseñanza Pública entre los años 1908 y $1912 .{ }^{59}$ Empero, es una deuda de este escrito el no haberse extendido en sus incidencias cotidianas.

\footnotetext{
${ }^{59}$ Félix Evaristo Mejía, Prosas polémicas 2. Temas educativos y discursos (Santo Domingo: Archivo General de la Nación, 2008); Neici Zeller, «Resistencias magisteriales a la política educacional del Gobierno Militar de Ocupación en la República Dominicana, 1916-1924» (ponencia presentada en el
} 
Se subraya otra vez el carácter exploratorio de este estudio y el sentido conceptual de los modelos de espacio escolar que aquí descritos. La escuela-aposento fue realidad indiscutible del desarrollo escolar dominicano hasta su paulatina disolución entre las reformas del Gobierno Militar y el ascenso de la dictadura trujillista. Como señalamos, brindó al Estado nacional la posibilidad de cumplir medianamente su compromiso ético con la ilustración y la elevación cultural futura del pueblo dominicano y llegó a alcanzar la difusión descrita.

Sin embargo, existía en el concierto de otros desarrollos de la configuración escolar de base claramente urbana, sostenidos por ayuntamientos ricos, sociedades confesionales, benéficas, artesanas, etc.

No todo era o había sido escuela-aposento en la vida educacional dominicana que comenzaba a transformarse a inicios del siglo xx. Como espacio primigenio de la enseñanza pública, de la entraña del domicilio de los docentes se gestaron también desarrollos que transitaron al espacio aislado, de uso estrictamente instruccional y a la enseñanza graduada. Esos espacios se insertaron con facilidad en el proceso de modernización y cambio que instauró el sistema de escuela pública de masas que propulsó la Ocupación.

En tanto trayectos en la historia de la formación del espacio escolar dominicano, los planteles confesionales y las escuelas de sociedades artesanas, culturales y filantrópicas, tendieron a contar con edificios aislados donde se desarrolló generalmente una enseñanza graduada. Sin embargo, no todos los pertenecientes a esas redes operaron en espacios aislados. Las «escuelas inglesas» de los negros protestantes de la península de Samaná, por ejemplo, asociaron típicamente la escuela con el templo, haciendo convivir rito y aprendizaje, cosa que les creó problemas con las política de control del Servicio Nacional de Instrucción Pública. ${ }^{60}$ También las escuelas parroquiales que funcionaban en templos católicos de las ciudades mayores se fundían con otras actividades de práctica en

Congreso Iberoamericano de Historia de la Educación Latinoamericana, Toluca, Estado de México, 6-9 de mayo, 2014).

${ }^{60}$ Juan Alfonseca, «Escolarización y minorías étnicas en la República Dominicana, 1918-1944», Cuadernos Interculturales, 6 (11), (2008). 
sus congregaciones. ${ }^{61}$ Las espacios escolares de las sociedades filantrópicas (Amantes de la Luz, La Progresista, La Democracia, etc.) también se compenetraban con otras prácticas institucionales, lo mismo que los gestados por sociedades mutuales de obreros y artesanos, por no citar aquí el caso de las formas de enseñanza generadas en el espacio mismo del proceso de trabajo, como los Lectores de las factorías de tabaco. ${ }^{62}$

En su gran mayoría, los planteles de esas instituciones fueron gratuitos, aunque también recibían alumnos "públicos» subvencionados por Ayuntamientos y gobiernos nacionales.

Tampoco con el advenimiento de las escuelas "Presidente Trujillo» en 1933 quedó completamente consolidado el moderno espacio escolar aislado de propiedad pública, gratuito. Pasarían años para que la escolarización del sistema escolar provisto por el Estado lograse hacerse presente en el común de las secciones rurales. Sin embargo, puede decirse que su surgimiento parece haber cancelado la reedición del modelo parcialmente público de la escuela-aposento.

Por último, vale la pena simplemente enunciar aquí la agenda de problemas historiográficos que abre el estudio de estos procesos de transformación del espacio y las relaciones sociales entramadas en el fomento de la enseñanza pública dominicana en el período estudiado:

1. Un primer problema atañe al interés conceptual del modelo aquí llamado escuela-aposento, pues parece materia poco tratada en los estudios de teoría histórica del espacio escolar, que tendieron a privilegiar el análisis del espacio escolar regido por el Estado, dejando de lado, entre penumbras, este tipo de formaciones semipúblicas, con su haz de procesos culturalmente peculiares, sus sociologías y sus antropologías políticas.

\footnotetext{
${ }^{61}$ José Luis Sáez, S. J., Autoridad para educar. Historia de la escuela católica dominicana (Santo Domingo: Archivo General de la Nación, 2008). El caso de los planteles confesionales es difícil de aprehender, pues claramente podría decirse que muchas escuelas-aposento particulares se vinculaban espiritual y prácticamente con el credo y sus asociaciones. Castellanos cita varios casos, entre ellos el del Notario Eclesiástico Juan Vicente Moscoso, «gloria y prez de cualquiera sociedad que en ciertas horas del día convertía su casa en escuela» hacia 1822 y a quien podríamos directamente captar como el correspondiente eclesiástico del mítico maestro Aybar. Rafael C. Castellanos, El Clero en Santo Domingo (Santo Domingo: Amigo del Hogar, 1997).

${ }^{62}$ Araceli Tinajero, El Lector. A History of the Cigar Factory Reader (Austin: University of Texas Press, 2010).
} 
Al menos en su vertiente clásica, esas teorizaciones se abocaron al análisis del espacio aislado, la emergencia de la escuela graduada y el desarrollo y concreción práctico-arquitectónica del pensamiento higienista en la pedagogía moderna. Pensamos, esencialmente, en los estudios hace tiempo realizados por Jaume Trilla, Antonio Viñao y Agustín Escolano, quienes apenas aluden al estadio formativo del que despega la emergencia de los sistema escolares públicos, principalmente al instalado en el domicilio del preceptor. ${ }^{63}$ También la bibliografía sobre las concreciones nacionales del movimiento higienista vino refiriéndolo al ilustrar el arcaismo del espacio domiciliar que se trataba de superar, pero su clave proversiva, pues la reflexión se centra en el futuro espacio normalizado dejando de lado la trama de relaciones socio-antropológicas que lo sustentaban. ${ }^{64}$ Debe destacarse el aporte relevante que realiza, en este sentido, la recientemente aparecida compilación de estudios nacionales sobre la formación de la escuela pública en América Latina que coordinan Alberto Martínez Boom y José Bustamante Vismara. ${ }^{65}$

2. Uno segundo problema alude a la relevancia que tendría reconocer los aportes de la sociedad civil a la formación histórica del sistema escolarización pública en la era moderna. Como en el aspecto anterior, también aquí ha preponderado un interés conceptualmente centrado en la figura (y la progenitura) del Estado político a la hora de periodizar históricamente el proceso. En el caso dominicano, pero también en otros del área latinoamericana, el aporte

\footnotetext{
${ }^{63}$ Antonio Viñao, «Del espacio escolar y la escuela como lugar: propuestas y cuestiones», Historia de la Educación, 12-13 (1993-1994); Agustín Escolano, Tiempos y espacios para la escuela (Madrid: Editorial Biblioteca Nueva, 2000); Jaume Trilla, Ensayos sobre la escuela. El espacio social y material de la escuela (Barcelona: Laertes, 1985).

${ }^{64}$ Un ejemplo de esa mirada proversiva en los estudios sobre el higienismo lo constituye la contribución reciente sobre higienismo y arquitectura escolar en Cuba del historiador Yoel Cordoví, que enuncia con nitidez la problemática del espacio doméstico al señalar: «en la agudización de la crítica situación de los locales docentes en el campo incidían los efectos de la politización de las instituciones escolares y su control por los órganos de poder local. Los vecinos de mayor representatividad en muchas de las comarcas rurales asistieron a una lucha encarnizada por el control de la distribución de los locales docentes con el propósito de usufructuar su alquiler, así como el sueldo del conserje y las cuotas que pudieran desembolsar el maestro o la maestra por los gastos en que incurriesen», sin involucrarse en su análisis. Yoel Cordoví Núñez, «Las casas-escuelas en Cuba: arquitectura e higienismo, 1899-1920», Revista Mexicana de Historia de la Educación, (4), (2014): 141-142.

${ }^{65}$ Alberto Martínez Boom y José Bustamante Vismara. Escuela pública y maestro en América Latina. Historias de un acontecimiento, Siglos XVIII-XIX (Buenos Aires: Prometeo, 2014).
} 
ciudadano a la formación del sistema escolar público fue definitivo, como lo evidencian el desarrollo del modelo domiciliar-privado en que se gestó la escuela-aposento y el asociacionismo que entregó gratuitamente al Estado sus recursos. ${ }^{66}$

3. El tercer problema que señalaremos aquí como materia de una agenda conceptual historiográfica es el del papel de las ocupación militar norteamericana en el lanzamiento del sistema centralizado de escuela pública en las sociedad dominicana. Como acaba de señalarse, la Ocupación pareció simplemente haber creado las condiciones de fuerza política para implantar ideas que se habían venido discutiendo desde inicios del siglo sobre el interés de centralizar la enseñanza, regular el influjo local en su fomento y en el reclutamiento del personal dirigente, etc. En el orden de las ideas pedagógicas, también fue la intelectualidad dominicana la que dio cuerpo a los programas de enseñanza reformados en ese lapso, imprimiéndoles aspectos del ideario hostosiano aunque incorporando también posiciones utilitaristas y el sesgo vocacional de la enseñanza norteamericana.

En este sentido, la epistemología de la escuela reformada durante la Ocupación halla soluciones de continuidad durante el trujillismo, que retoma elementos del diseño de la Escuela Rudimentaria implantada en 1918, como el fomento a las asociaciones locales, la enseñanza orientada a la vida, el huerto escolar, entre otros rasgos coherentes con los planteamientos de la Escuela Nueva entonces en boga.

\section{Nota sobre el autor}

Juan B. Alfonseca Giner de los Ríos es dominicano. Realizó estudios de grado y posgrado en ciencias sociales en la Universidad Nacional Autónoma de México y la Facultad Latinoamericana de Ciencias Sociales (sede México). Labora como docente e investigador en el Instituto Superior de Ciencias de la Educación del Estado de México. Ha desarrollado investigación histórica en materia de política educativa y escolarización en contextos rurales de México y la República Dominicana durante la primera

${ }^{66}$ Ariadna Acevedo, «Paying for Progress: Politics, Ethnicity and Schools in a Mexican Sierra, 18751930» (Tesis Doctoral, Universidad de Warwick, 2004). 
mitad del siglo xx. Forma parte del Sistema Nacional de Investigadores del Consejo Nacional de Ciencia y Tecnología. Es miembro fundador de la Sociedad Mexicana de Historia de la Educación (SOMEHIDE) y ha formado regularmente parte de comités organizadores de eventos especializados en la historia de la educación. Cuenta con diversas publicaciones sobre los procesos de escolarización en el medio rural.

\section{REFERENCIAS}

Acevedo, Ariadna. "Paying for Progress: Politics, Ethnicity and Schools in a Mexican Sierra, 1875-1930». PhD diss., Universidad de Warwick, 2004.

AlfonsecA, Juan. «Escolarización y minorías étnicas en la República Dominicana, 1918-1944». Cuadernos Interculturales 6 (11), (2008): 17-45.

- «Escolarización y dictadura. La escuela rural y el encuadramiento del campesinado en la República Dominicana (1930-1940)». Boletín del Archivo General de la Nación 36 (130), (2011): 375-405.

- "A Public School System. Ensayo sobre un concepto en la representación imperial norteamericana sobre la escuela popular en las Antillas, 1898-1934». In El lenguaje de la educación: conceptos, metáforas y narrativas en los orígenes de los sistemas educativos nacionales (c.1870-1930), edited by Eugenia Roldán Vera. Frankfurt am Main: Peter Lang.

Angulo A. J. Empire and Education. A History of Greed and Goodwill from the War of 1898 to the War on Terror. New York: Palgrave Macmillan, 2012.

Bosch, Juan. «Una escuela rural hace veinte años». Revista de Educación 6 (27), (1935): 70-73.

BROCKLISS, Laurence y Nicola SHELDON. «General Introduction». In Mass schooling and the limits of State Building, c. 1870-1930, edited by Laurence Brockliss y Nicola Sheldon, 1-12. Londres: Palgrave Macmillan, 2012.

CALDER, Bruce. El impacto de la intervención. La República Dominicana durante la Ocupación Norteamericana de 1916-1924. Santo Domingo: Fundación Cultural Dominicana, 1989.

Castellanos, Rafael. El Clero en Santo Domingo. Santo Domingo: Amigo del Hogar, 1997.

CLARK, Victor. «Report on Public Schools of Puerto Rico». In Report of the Major-General commanding the army, edited by War Department, 639-677. Washington: Goverment Printing Office, 1899.

Cordoví NuÑEz, Yoel. "Las casas-escuelas en Cuba: arquitectura e higienismo, 1899-1920». Revista Mexicana de Historia de la Educación 4 (2014): 131-151.

DE los SANTOS, Danilo. «El pensamiento y la institución educativa en la sociedad dominicana». Revista Eme-Eme 6 (33), (1977): 14-69. 
- «El pensamiento y la institución educativa en la sociedad dominicana». $R e$ vista Eme-Eme 6 (34), (1978): 40-124.

EPSTEIN, Erwin. «The Peril of Paternalism: The Imposition of Education on Cuba by the United States». American Journal of Education 96 (1), (1987): 1-23.

EQUiPo DE INVESTIGACIONES SOCIALES. «La educación bajo la dictadura trujillista: una bibliografía». Ciencia y Sociedad 12 (1), (1987): 121-133.

Escolano, Agustín. Tiempos y espacios para la escuela. Madrid: Editorial Biblioteca Nueva, 2000.

Fiallo, José A. y Alejandrina Germán. Formación de maestros y maestras en República Dominicana, 1844-1992. Santo Domingo: INTEC, 1999.

Go, Julian. "Chains of Empire, Projects of State: Political Education and U.S. Colonial Rule in Puerto Rico and the Philippines». Comparative Studies in Society and History 42 (2), (2000): 333-362.

Gobierno Dominicano. Constitución politica y reformas constitucionales 18441942 Tomo I. Santiago de los Caballeros: Editorial El Diario, 1934.

GonzÁlez, Raymundo. Documentos para la historia de la educación moderna en la República Dominicana (1879-1894). Tomo I y II. Santo Domingo: Archivo General de La Nación, 2007.

Hernández Figueroa, Alfredo. La Vega, 25 años de historia. 1861 - 1886. Tomo II. Santo Domingo: Archivo General de la Nación, 2007.

LANE, Rufus. "Civil Government in Santo Domingo in the Early Days of Military Occupation». The Marine Corps Gazette 7 (2), (1922): 127-146.

LINDSAY, Samuel. "Inauguration of the American School System in Porto Rico». In Report of the Commissioner of Education for the year ending june 30, 1905, edited by Comissioner of Education of Porto Rico, 293-339. Washington: Government Printing Office, 1907.

Marshall, James D. "Foucault y la investigación educativa». In Foucault y la educación. Disciplinas y saber, edited by Stephen J. Ball, 15-33. Madrid: Ediciones Morata, 1994.

Martínez Boom, Alberto y José Bustamante Vismara. Escuela pública y maestro en América Latina. Historias de un acontecimiento, Siglos XVIII-XIX. Buenos Aires: Prometeo, 2014.

Mejía, Félix Evaristo. Prosas polémicas 2. Temas educativos y discursos. Santo Domingo: Archivo General de la Nación, 2008.

Moquete, Jacobo. Filosofía y política de la educación dominicana. Santo Domingo: Editora Universitaria, 1986.

Morrison, Ramón. Historia de la educación en la República Dominicana (Desde sus más remotos orígenes hasta 1900). Santo Domingo: Editora Taller, 1995. 
Newland, Carlos. «The Estado Docente and Its Expansion: Spanish American Elementary Education, 1900-1950». Journal of Latin American Studies 26 (2), (1994): 449-467.

Nivar, Consuelo. Sistema educativo en la República Dominicana. Ciudad Trujillo: Librería Dominicana, 1952.

Palacín, Gregorio B. "Cien años de educación nacional». Revista de Educación 14 (73), (1944): 39-69.

— «Cien años de educación nacional». Revista de Educación 14 (74), (1944): 7-31.

Pamphile, Leon D. Clash of Cultures. America's educational strategies in occupied Haiti, 1915-1934. Maryland: University Press of America, 2008.

Pimentel, Francisco Antonio. Historia de la educación en la República Dominicana. Santo Domingo: Editora Centenario, 2003.

PopkewITz, Thomas. Sociología politica de las reformas educativas. Madrid: Ediciones Morata, 1994.

Rodríguez Demorizi, Emilio. Sociedades, cofradías, escuelas, gremios y otras corporaciones dominicanas. Santo Domingo: Editora Educativa Dominicana, 1975.

ROLDÁN VERA, Eugenia. «Instrucción pública, educación pública y escuela pública: Tres conceptos clave en los orígenes de la nación mexicana, 1780-1833». In Escuela Pública y Maestro en América Latina. Historias de un acontecimiento, siglos XVIII-XIX, edited by Alberto Martínez Boom y José Bustamante Vismara, 61-91. Buenos Aires, Prometeo, 2014.

SÁez, José Luis. Autoridad para educar. Historia de la escuela católica dominicana. Santo Domingo: Archivo General de la Nación, 2008.

SANTOS, Roberto. Pasado, presente y perspectivas de la educación nacional institucionalizada. Santo Domingo: Editora Alfa y Omega, 1983.

TinaJERo, Araceli. El Lector. A History of the Cigar Factory Reader. Austin: University of Texas Press, 2010.

TRILlA, Jaume. Ensayos sobre la escuela. El espacio social y material de la escuela. Barcelona: Laertes, 1985.

TURITS, Richard. "The foundations of despotism. Agrarian reform, rural transformation, and Peasant-State compromise in Trujillo's Dominican Republic, 1930-1944». In Identity and struggle at the margins of the nation-state. The laboring peoples of Central America and the Hispanic Caribbean, edited by Aviva Chomsky, 292-334. Durham: Duke University Press, 1998.

United States Military Government of Santo Domingo. Santo Domingo: Its Past and Its Present Condition. Santo Domingo: s.e., 1920.

United States SenATE. Inquiry into the Occupation and Administration of Haiti and Santo Domingo. Washington: Government Printing Office, 1921. 
VIÑAO, Antonio. «Del espacio escolar y la escuela como lugar: propuestas y cuestiones». Historia de la Educación 12-13 (1993-1994): 17-74.

ZELler, Neici. Discursos y espacios femeninos en República Dominicana, 18801961. Santo Domingo: Letra Gráfica, 2012.

- «Resistencias magisteriales a la política educacional del Gobierno Militar de Ocupación en la República Dominicana, 1916-1924». Paper presented at Congreso Iberoamericano de Historia de la Educación Latinoamericana, Toluca, Estado de México, May 6-9, 2014. 